Article

\title{
Synthesis, Characterization, and Self-Assembly of a Tetrathiafulvalene (TTF)-Triglycyl Derivative
}

\author{
Sónia Pérez-Rentero ${ }^{1,2}$, Ramon Eritja ${ }^{1,2, * \mathbb{B} \text {, Marleen Häring }}{ }^{3}$, César Saldías ${ }^{4}$ \\ and David Díaz Díaz ${ }^{1,3}$,* \\ 1 Institute of Advanced Chemistry of Catalonia-Spanish National Research Council (IQAC-CSIC), \\ Jordi Girona 18-26, 08034 Barcelona, Spain; sonia.perez@iqac.csic.es \\ 2 Networking Centre in Bioengineering, Biomaterials and Nanomedicine (CIBER-BBN), Jordi Girona 18-26, \\ 08034 Barcelona, Spain \\ 3 Institut für Organische Chemie, Universität Regensburg, Universitätsstr. 31, 93053 Regensburg, Germany; \\ Marleen.Haering@chemie.uni-regensburg.de \\ 4 Departamento de Química Física, Facultad de Química, Pontificia Universidad Católica de Chile, Casilla 302, \\ Correo 22, 7820436 Santiago, Chile; casaldia@uc.cl \\ * Correspondence: recgma@cid.csic.es or ramon.eritja@iqac.csic.es (R.E.); \\ david.diaz@chemie.uni-regensburg.de (D.D.D.); Tel.: +34-934006145 (R.E.); +49-941-943-4373 (D.D.D.); \\ Fax: +49-941-943-4121 (D.D.D.)
}

Received: 3 April 2018; Accepted: 23 April 2018; Published: 26 April 2018

\begin{abstract}
In this work, we describe the synthesis, characterization, and self-assembly properties of a new tetrathiafulvalene (TTF)-triglycyl low-molecular-weight (LMW) gelator. Supramolecular organogels were obtained in various solvents via a heating-cooling cycle. Critical gelation concentrations (CGC) (range $\approx 5-50 \mathrm{~g} / \mathrm{L}$ ) and thermal gel-to-sol transition temperatures $\left(T_{\text {gel }}\right)$ (range $\approx 36-51^{\circ} \mathrm{C}$ ) were determined for each gel. Fourier transform infrared (FT-IR) spectroscopy suggested that the gelator is also aggregated in its solid state via a similar hydrogen-bonding pattern. The fibrillar microstructure and viscoelastic properties of selected gels were demonstrated by means of field-emission electron microscopy (FE-SEM) and rheological measurements. As expected, exposure of a model xerogel to $\mathrm{I}_{2}$ vapor caused the oxidation of the TTF unit as confirmed by UV-vis-NIR analysis. However, FT-IR spectroscopy showed that the oxidation was accompanied with concurrent alteration of the hydrogen-bonded network.
\end{abstract}

Keywords: tetrathiafulvalene; triglycyl peptide; self-assembly; organogel

\section{Introduction}

Oligonucleotide conjugates carrying aromatic systems are important tools for a large number of applications due to their enhanced hybridization properties and their special fluorescence and chemical properties coming from the aromatic moieties [1-6]. Recently, tetrathiafulvalene (TTF) derivatives have been incorporated in oligonucleotides demonstrating the fluorescence-quenching properties of the DNA-TTF conjugates upon hybridization [7], the preservation of the electrochemical properties of TTF [8], an enhanced affinity to complementary sequences [9], and compatibility with the RNA interference mechanism for gene inhibition [10]. In the field of materials chemistry, TTF and its derivatives constitute electron donors that can form charge-transfer (CT) complexes and have been widely studied for the development of electrically conducting materials [11,12]. TTF moiety can be consecutively oxidized to the radical cation $\mathrm{TTF}^{+}$and dication $\mathrm{TTF}^{2+}$ by either electrochemical or chemical processes. Due to the reversibility of these transformations [13], TTF has become a general building block for the fabrication of switchable functional materials [14-17], including supramolecular self-assembled nanostructures [18-21]. 
The interesting properties of the TTF-oligonucleotides prompted us to synthesize a TTF derivative carrying a biodegradable triglycyl peptide linker between the oligonucleotide and the TTF molecule. This simple peptide sequence has been demonstrated to be hydrolyzed by cathepsin B present in endosomes [22]. During the preparation of the mentioned TTF derivative we accidentally observed the formation of gels in some solvents. In general, gels have received great attention during the last decade [23-34] due to their exceptional hierarchical architectures and potential applications in many important areas such as biomedicine, health care, and catalysis, among others [35-45]. Chemical gels are based on covalent bonds, usually cross-linked polymers [46-48], whereas physical gels (also called supramolecular gels) are normally fabricated using low-molecular-weight (LMW) molecules that self-assembly via non-covalent interactions. For this reason, supramolecular gels usually show reversible stimuli-responsive gel-to-sol transitions [23,24]. Systems based on both covalent and non-covalent interactions are also known [49]. Typically, the entanglement of 1D nanofibers of gelator molecules generates a 3D-network with the solvent molecules trapped into the interstices by capillary forces. This provides a solid-like appearance and viscoelastic features to physical gels [50-53].

Within this context, Jørgensen and co-workers reported in 1994 [54] the first TTF-based LMW gelator bearing bis-arborol units, which was used to fabricate a self-assembling "molecular" nanowire [55]. Since then, a large number of electroactive TTF-based LMW gelators and their gels have been described in the literature [56]. In general, the rational design behind these examples involves the connection of the TTF unit with groups capable of H-bonding, such as urea [57] or amide groups [58-63], to form extended structures. The incorporation of other molecular building blocks commonly used to form physical gels [64-67] or the use of metal-organic interactions [68-70] have also been employed to form TTF-based gels. Moreover, the inclusion of hydrophobic aliphatic chains is also employed to facilitate van der Waals interactions and stabilize the supramolecular aggregates [58-71]. If formation of CT complexes takes place, the TTF unit will bear positive charge, which can alter the interaction of neighboring TTF units and influence the intermolecular interactions arising from other groups involved in the self-assembly process. Indeed, the above-mentioned studies have confirmed the possibility of tuning the gel formation by $\mathrm{CT}$ interaction and oxidation. In addition, conductive gels have also been fabricated by simple mixing and mechanically grinding neutral TTF and an acceptor (i.e., tetracyanoquinodimethane) in ionic liquids [72]. More recently, gels made of TTF-dipeptide and tripeptide conjugates have been reported $[73,74]$.

In this communication we describe the synthesis, characterization, and gelation properties of a new TTF-triglycyl-based LMW organogelator (Figure 1). As far as we are aware, a triglycyl peptide has not been used to fabricate TTF-based gelators.

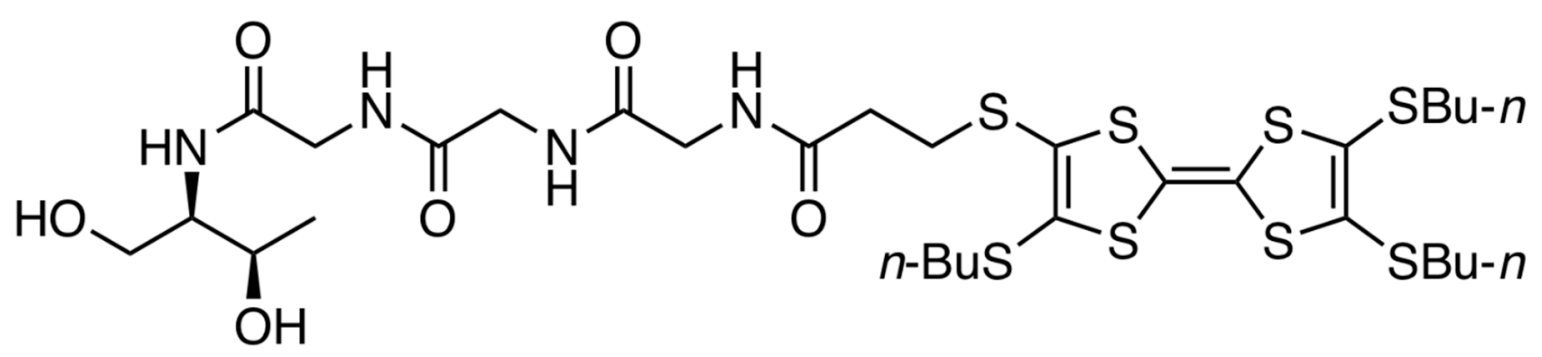

Figure 1. Chemical structure of tetrathiafulvalene (TTF)-triglycyl derivative studied in this work.

\section{Materials and Methods}

\subsection{Materials}

Unless otherwise noted, all reagents and dry solvents were purchased from commercial suppliers (Sigma-Aldrich, St. Louis, MO, USA, TCI Chemicals, Tokyo, Japan) and used as received. 


\subsection{Synthesis and Characterization of Compounds}

\subsubsection{General Remarks}

Nuclear magnetic resonance (NMR) spectra, ${ }^{1} \mathrm{H}-\mathrm{NMR}(400 \mathrm{MHz})$, and ${ }^{13} \mathrm{C}-\mathrm{NMR}(100 \mathrm{MHz})$ were recorded using Varian Mercury 400 spectrometer at room temperature (RT). Tetramethylsilane (TMS) was used as internal reference $(0 \mathrm{ppm})$ for ${ }^{1} \mathrm{H}$ spectra recorded in $\mathrm{CDCl}_{3}$. Chemical shifts for ${ }^{1} \mathrm{H}-\mathrm{NMR}$ and ${ }^{13} \mathrm{C}-\mathrm{NMR}$ were reported as $\delta$, parts per million (ppm), relative to the signal of the residual solvent $\left({ }^{1} \mathrm{H}-\mathrm{NMR}: \mathrm{CHCl}_{3}=7.26 \mathrm{ppm}, \mathrm{DMSO}=2.50 \mathrm{ppm} ;{ }^{13} \mathrm{C}-\mathrm{NMR}: \mathrm{CHCl}_{3}=77.16 \mathrm{ppm}, \mathrm{DMSO}=39.5 \mathrm{ppm}\right.$; $\left.\mathrm{CD}_{3} \mathrm{OD}=49.0 \mathrm{ppm}\right)$. Coupling constants $(J)$ are given in Hertz $(\mathrm{Hz})$. Multiplicity notations: $\mathrm{s}=$ singlet, $\mathrm{bs}=$ broad singlet, $\mathrm{d}=$ doublet, $\mathrm{t}=$ triplet, $\mathrm{q}=$ quartet, $\mathrm{dd}=$ doublet of doublets, $\mathrm{m}=$ multiplet. Estimated error of reported values: $0.01 \mathrm{ppm}\left(\delta,{ }^{1} \mathrm{H}-\mathrm{NMR}\right), 0.1 \mathrm{ppm}\left(\delta,{ }^{13} \mathrm{C}-\mathrm{NMR}\right), 0.1 \mathrm{~Hz}(J$, coupling constant). Copies of the NMR spectra are provided in the Supporting Information. Fourier transform infrared (FT-IR) spectra were recorded on a Thermo-Nicolet Avatar 380 FT-IR equipped with a SMART iTR sampling accessory. Electrospray ionization mass spectra (ESI-MS) were recorded on a Micromass ZQ instrument with single quadrupole detector coupled to an HPLC and high-resolution (HR) ESI-MS on an Agilent 1100 LC/MS-TOF instrument (Servei d'Espectrometría de Masses, Universitat de Barcelona). Flash chromatography was performed using silica gel (230-400 mesh) as stationary phase. Thin-layer chromatography (TLC) analysis were carried out on silica gel $60 \mathrm{~F}_{254}$ aluminum sheets and visualized under UV light (365 nm).

\subsubsection{Synthetic Procedures and Characterization of Compounds}

4,5-Bis-(butylthio)-1,3-dithiole-2-thione (3): A mixture of bis(tetrabutylammonium) bis(1,3-dithiole-2-thione4,5-dithiolate) zinc (1, TCI chemicals) $(2.18 \mathrm{~g}, 2.30 \mathrm{mmol})$ and 1-bromobutane (2, Sigma-Aldrich) $(1.24 \mathrm{~mL}, 11.50 \mathrm{mmol})$ in anhydrous acetonitrile (ACN) $(30 \mathrm{~mL})$ was refluxed for $1 \mathrm{~h}$. The initially formed reddish solution turned into a green-yellowish mixture. Once the solution was cooled to room temperature (RT), the precipitate was filtered out and the solution mixture was concentrated to dryness under reduced pressure. The residue was dissolved in dichloromethane (DCM) $(50 \mathrm{~mL})$ and the organic phase was washed with water $(4 \times 30 \mathrm{~mL})$. The organic phase was dried over anhydrous $\mathrm{MgSO}_{4}$ and concentrated to dryness under reduced pressure. The residue was purified by flash chromatography on silica gel (hexane/ ethyl acetate (AcOEt) 1:1) affording the desired compound 3 as reddish oil (1.40 $\mathrm{g}$, 98\% yield). TLC in AcOEt/hexane 10:0.1, $\mathrm{R}_{f}=0.85 .{ }^{1} \mathrm{H}-\mathrm{NMR}\left(400 \mathrm{MHz}, \mathrm{CDCl}_{3}\right) \delta(\mathrm{ppm}): 2.85(\mathrm{t}$, $\left.J=7.3 \mathrm{~Hz}, 4 \mathrm{H},=\mathrm{C}-\mathrm{SCH}_{2}-\right), 1.67-1.59\left(\mathrm{~m}, 4 \mathrm{H},=\mathrm{C}-\mathrm{SCH}_{2}-\mathrm{CH}_{2}-\right), 1.48-1.38\left(\mathrm{~m}, 4 \mathrm{H},=\mathrm{C}^{-} \mathrm{SCH}_{2}-\mathrm{CH}_{2}-\mathrm{CH}_{2}-\right)$, $0.91\left(\mathrm{t}, J=7.3 \mathrm{~Hz}, 6 \mathrm{H}, \mathrm{CH}_{3}\right) .{ }^{13} \mathrm{C}-\mathrm{NMR}\left(100 \mathrm{MHz}, \mathrm{CDCl}_{3}\right) \delta$ (ppm): 211.49 (C=S), 136.34 (S-C-S), 36.42 $\left(\mathrm{S}-\mathrm{CH}_{2}-\right), 31.64\left(\mathrm{~S}-\mathrm{CH}_{2}-\mathrm{CH}_{2}-\right), 21.63\left(\mathrm{~S}-\mathrm{CH}_{2}-\mathrm{CH}_{2}-\mathrm{CH}_{2}-\right), 13.51\left(-\mathrm{CH}_{3}\right)$. IR (oil): $v=2954 \mathrm{~m}, 2925 \mathrm{~m}$ and $2869 \mathrm{w}$ (C-H stretch), $1461 \mathrm{~m}$ (H-C-H bend), $1060 \mathrm{~s}$ (C=S stretch), $884 \mathrm{~m}$ (H-C-S bend), $742 \mathrm{w}$ (C-S stretch) $\mathrm{cm}^{-1}$. HRMS $\left(\mathrm{ESI}^{+}\right): \mathrm{m} / z$ : calcd for $\mathrm{C}_{11} \mathrm{H}_{19} \mathrm{~S}_{5}\left([\mathrm{M}+\mathrm{H}]^{+}\right)$311.0090; found 311.0084

2,3-Bis(2-cyanoethylthio)-6,7-bis(butylthio)tetrathiafulvalene (5): A mixture of 4,5-bis(2-cyanoethylthio)1,3-dithiol-2-one (4, Sigma-Aldrich) $(1 \mathrm{~g}, 3.47 \mathrm{mmol})$ and compound $3(1.3 \mathrm{~g}, 4.16 \mathrm{mmol})$ was dried by successive evaporation of dry $\mathrm{ACN}(\times 3)$ followed by storage in a desiccator. The residue was dissolved in trimethyl phosphite $(40 \mathrm{~mL})$ and the solution heated gradually to reach $110{ }^{\circ} \mathrm{C}$ under argon atmosphere. The solution was stirred for $2 \mathrm{~h}$ at $110^{\circ} \mathrm{C}$ and subsequently allowed to cool RT. The mixture was concentrated to dryness and the residue was treated with toluene and evaporated $(\times 4)$ in order to eliminate the excess of trimethyl phosphite. The obtained residue was purified by flash chromatography on silica gel (DCM/hexane 8:2 to pure DCM) affording the desired compound 5 as a yellow solid (1.22 g, 64\% yield). TLC in DCM/hexane 10:0.1, $\mathrm{R}_{f}=0.38 .{ }^{1} \mathrm{H}-\mathrm{NMR}\left(400 \mathrm{MHz}, \mathrm{CDCl}_{3}\right) \delta$ (ppm): $3.07\left(\mathrm{t}, J=7.2 \mathrm{~Hz}, 4 \mathrm{H},=\mathrm{C}-\mathrm{SCH}_{2}-\mathrm{CH}_{2}-\mathrm{CN}\right), 2.81\left(\mathrm{t}, J=7.2 \mathrm{~Hz}, 4 \mathrm{H},=\mathrm{C}-\mathrm{SCH}_{2}-\mathrm{CH}_{2}-\mathrm{CH}_{2}-\mathrm{CH}_{3}\right)$, $2.72\left(\mathrm{t}, J=7.2 \mathrm{~Hz}, 4 \mathrm{H},=\mathrm{C}-\mathrm{SCH}_{2}-\mathrm{CH}_{2}-\mathrm{CN}\right), 1.64-1.56\left(\mathrm{~m}, 4 \mathrm{H}, \mathrm{C}-\mathrm{SCH}_{2}-\mathrm{CH}_{2}-\mathrm{CH}_{2}-\mathrm{CH}_{3}\right), 1.47-1.38(\mathrm{~m}$, $\left.4 \mathrm{H}, \mathrm{C}-\mathrm{SCH}_{2}-\mathrm{CH}_{2}-\mathrm{CH}_{2}-\mathrm{CH}_{3}\right), 0.91\left(\mathrm{t}, J=7.3 \mathrm{~Hz}, 6 \mathrm{H}, \mathrm{CH}_{3}\right) .{ }^{13} \mathrm{C}-\mathrm{NMR}\left(100 \mathrm{MHz}, \mathrm{CDCl}_{3}\right) \delta(\mathrm{ppm})$ : 127.95 and $127.82(\mathrm{~S}-\mathrm{C}-\mathrm{S}), 117.40(\mathrm{CN}), 114.75(\mathrm{C}=\mathrm{C}), 106.38(\mathrm{C}=\mathrm{C}), 36.02\left(\mathrm{~S}-\mathrm{CH}_{2}-\right), 31.70\left(\mathrm{~S}-\mathrm{CH}_{2}-\mathrm{CH}_{2}-\right)$, 
$31.23\left(\mathrm{~S}-\mathrm{CH}_{2}-\mathrm{CH}_{2}-\mathrm{CN}\right), 21.60\left(\mathrm{~S}-\mathrm{CH}_{2}-\mathrm{CH}_{2}-\mathrm{CH}_{2}-\right), 18.89\left(\mathrm{~S}-\mathrm{CH}_{2}-\mathrm{CH}_{2}-\mathrm{CN}\right), 13.57$ (-CH$)$. IR (solid): $v=2954 \mathrm{~m}, 2924 \mathrm{~m}$ and $2869 \mathrm{~m}$ (C-H stretch), $2249 \mathrm{w}$ (C $\equiv \mathrm{N}$ stretch), $1457 \mathrm{w}$ (H-C-H bend), $1415 \mathrm{~m}-\mathrm{s}$ (H-C-H bend), $889 \mathrm{~s}$ (H-C-S bend), $771 \mathrm{~s}\left(\mathrm{C}-\mathrm{S}\right.$ stretch) $\mathrm{cm}^{-1}$. HRMS (ESI ${ }^{+}$: $m / z$ : calcd for $\mathrm{C}_{20} \mathrm{H}_{27} \mathrm{~N}_{2} \mathrm{~S}_{8}$ $\left([\mathrm{M}+\mathrm{H}]^{+}\right)$550.9940; found 550.9956 .

2-(2-Cyanoethylthio)-3,6,7-tris(butylthio)tetrathiafulvalene (6): A solution of $\mathrm{CsOH} \cdot \mathrm{H}_{2} \mathrm{O}(365 \mathrm{mg}$, $2.12 \mathrm{mmol})$ in dry methanol $(\mathrm{MeOH})(15 \mathrm{~mL})$ was added dropwise over a period of $30 \mathrm{~min}$ to a stirred solution of TTF derivative $5(1.13 \mathrm{~g}, 2.07 \mathrm{mmol})$ in tetrahydrofuran (THF) $(40 \mathrm{~mL})$. The resulting orange solution was stirred for $30 \mathrm{~min}$ at RT. To this solution, 1-bromobutane $(2)(0.44 \mathrm{~mL}, 4.14 \mathrm{mmol})$ dissolved in THF $(15 \mathrm{~mL})$ was added and the resulting mixture was stirred overnight (o.n.) at RT under nitrogen atmosphere. The mixture was concentrated to dryness and the resulting oil was purified by flash chromatography on silica gel (DCM/hexane 1:1 $\rightarrow 2: 1$ ) giving the desired compound 6 as an orange solid (1.09 g, 89\% yield). TLC in DCM/hexane 2:1, $\mathrm{R}_{f}=0.45 .{ }^{1} \mathrm{H}-\mathrm{NMR}\left(400 \mathrm{MHz}, \mathrm{CDCl}_{3}\right) \delta$ (ppm): $3.01\left(\mathrm{t}, J=7.2 \mathrm{~Hz}, 2 \mathrm{H}, \mathrm{SCH}_{2}-\mathrm{CH}_{2}-\mathrm{CN}\right), 2.87-2.78\left(\mathrm{~m}, 6 \mathrm{H}, \mathrm{SCH}_{2}-\mathrm{CH}_{2}-\mathrm{CH}_{2}-\mathrm{CH}_{3}\right), 2.68(\mathrm{t}, J=7.2 \mathrm{~Hz}$, $\left.2 \mathrm{H}, \mathrm{SCH}_{2}-\mathrm{CH}_{2}-\mathrm{CN}\right), 1.65-1.57\left(\mathrm{~m}, 6 \mathrm{H}, \mathrm{SCH}_{2}-\mathrm{CH}_{2}-\mathrm{CH}_{2}-\mathrm{CH}_{3}\right), 1.47-1.38\left(\mathrm{~m}, 6 \mathrm{H}, \mathrm{SCH}_{2}-\mathrm{CH}_{2}-\mathrm{CH}_{2}-\mathrm{CH}_{3}\right)$, 0.93-0.89 (m, 9H, $\left.\mathrm{CH}_{3}\right) .{ }^{13} \mathrm{C}-\mathrm{NMR}\left(100 \mathrm{MHz}, \mathrm{CDCl}_{3}\right) \delta(\mathrm{ppm}): 133.71,127.92,127.61$ and 121.83 $\left(-\mathrm{CH}_{2}-\mathrm{S}-\mathrm{C}-\mathrm{S}-\right), 117.53(\mathrm{CN}), 112.36$ and $108.27\left(\mathrm{~S}_{2} \mathrm{C}=\mathrm{CS}_{2}\right), 36.02$ and $35.98\left(\mathrm{~S}-\mathrm{CH}_{2}-\right), 31.77$ and 31.73 ( $\left.\mathrm{S}-\mathrm{CH}_{2}-\mathrm{CH}_{2}-\right), 31.24\left(\mathrm{~S}-\mathrm{CH}_{2}-\mathrm{CH}_{2}-\mathrm{CN}\right), 21.62\left(\mathrm{~S}-\mathrm{CH}_{2}-\mathrm{CH}_{2}-\underline{C H}_{2}-\right), 18.69\left(\mathrm{~S}_{-}-\mathrm{CH}_{2}-\underline{C H}_{2}-\mathrm{CN}\right), 13.57$ and $13.53\left(-\mathrm{CH}_{3}\right)$. IR (solid): $v=2954 \mathrm{~s}, 2925 \mathrm{~s}$ and $2870 \mathrm{~m}$ (C-H stretch), $2250 \mathrm{w}$ (C $\equiv \mathrm{N}$ stretch), $1463 \mathrm{~m}$ (H-C-H bend), $1412 \mathrm{~m}$ (C-H stretch), $890 \mathrm{~s}$ (H-C-S bend), $772 \mathrm{~m}$-s and $742 \mathrm{~m}$-s (C-S stretch) $\mathrm{cm}^{-1}$. HRMS (ESI ${ }^{+}$): $m / z$ : calcd for $\mathrm{C}_{21} \mathrm{H}_{31} \mathrm{NS}_{8}$ 554.0300; found 554.0288.

3-\{[4',5,5'-Tris(butylsulfanyl)-2,2'-bi-1,3-dithiol-4-yl]sulfanyl $\}$ propionic acid (8): (2-Cyanoethyl)sulfanyl TTF derivative $6(1.01 \mathrm{~g}, 1.82 \mathrm{mmol})$ was dissolved in anhydrous THF $(40 \mathrm{~mL})$ and a solution of $\mathrm{CsOH} \cdot \mathrm{H}_{2} \mathrm{O}(0.32 \mathrm{~g}, 1.9 \mathrm{mmol})$ in anhydrous $\mathrm{MeOH}(15 \mathrm{~mL})$ was added. After stirring the reaction mixture at RT for $30 \mathrm{~min}$, a suspension of 3-bromopropionic acid (7, Sigma-Aldrich) (0.56 g, $3.6 \mathrm{mmol})$ and freshly annealed $\mathrm{K}_{2} \mathrm{CO}_{3}(1.39 \mathrm{~g}, 10 \mathrm{mmol})$ in anhydrous $\mathrm{MeOH}(15 \mathrm{~mL})$ was added. The reaction mixture was stirred at RT for $3 \mathrm{~h}$ and concentrated to dryness. The obtained residue was dissolved in $\mathrm{Et}_{2} \mathrm{O}(230 \mathrm{~mL})$ and $1 \mathrm{M} \mathrm{HCl}$ aqueous solution $(150 \mathrm{~mL})$ was added slowly. The organic phase was washed with water $(100 \mathrm{~mL})$ and brine $(100 \mathrm{~mL})$, dried over anhydrous $\mathrm{MgSO}_{4}$ and concentrated to dryness under reduced pressure. The obtained residue was purified by chromatography on silica gel (DCM/MeOH 100:0 $\rightarrow 90: 10$ ) affording the desired compound 8 as an orange solid (0.95 g, 91\% yield). TLC in DCM/MeOH 10:0.5, $\mathrm{R}_{f}=0.50 .{ }^{1} \mathrm{H} \mathrm{NMR}\left(400 \mathrm{MHz}, \mathrm{CDCl}_{3}\right), \delta(\mathrm{ppm}): 3.03(\mathrm{t}, J=7.2 \mathrm{~Hz}, 2 \mathrm{H}$, $\left.\mathrm{SCH}_{2}-\mathrm{CH}_{2}-\mathrm{COOH}\right), 2.83-2.79\left(\mathrm{~m}, 6 \mathrm{H}, \mathrm{SCH}_{2}-\mathrm{CH}_{2}-\mathrm{CH}_{2}-\mathrm{CH}_{3}\right), 2.72\left(\mathrm{t}, J=7.2 \mathrm{~Hz}, 2 \mathrm{H}, \mathrm{SCH}_{2}-\mathrm{CH}_{2}-\mathrm{COOH}\right)$, 1.63-1.56 (m, 6H, C-SCH$\left.-\mathrm{CH}_{2}-\mathrm{CH}_{2}-\mathrm{CH}_{3}\right), 1.47-1.37\left(\mathrm{~m}, 6 \mathrm{H}, \mathrm{C}-\mathrm{SCH}_{2}-\mathrm{CH}_{2}-\mathrm{CH}_{2}-\mathrm{CH}_{3}\right), 0.91(\mathrm{t}, J=7.2 \mathrm{~Hz}$, $\left.9 \mathrm{H}, \mathrm{CH}_{3}\right) .{ }^{13} \mathrm{C}-\mathrm{NMR}\left(100 \mathrm{MHz}, \mathrm{CDCl}_{3}\right) \delta(\mathrm{ppm}): 176.78(\mathrm{COOH}), 131.10,127.87,127.61$ and 124.70 (- $\left.\mathrm{CH}_{2}-\mathrm{S}-\mathrm{C}-\mathrm{S}-\right), 111.17$ and $109.22\left(\mathrm{~S}_{2} \mathrm{C}=\mathrm{CS}_{2}\right), 35.99$ and $36.96\left(\mathrm{~S}-\mathrm{CH}_{2}-\right), 34.41\left(\mathrm{SCH}_{2}-\mathrm{CH}_{2}-\mathrm{COOH}\right), 31.74$ (S- $\left.\mathrm{CH}_{2}-\mathrm{CH}_{2}-\right), 30.48\left(\mathrm{SCH}_{2}-\mathrm{CH}_{2}-\mathrm{COOH}\right), 21.63\left(\mathrm{~S}^{-} \mathrm{CH}_{2}-\mathrm{CH}_{2}-\mathrm{CH}_{2}-\right), 13.57$ and $13.54\left(-\mathrm{CH}_{3}\right)$. IR (solid): $v=2956 \mathrm{~m}, 2912 \mathrm{~m}$ and $2854 \mathrm{~m}$ (C-H stretch), $1704 \mathrm{~s}$ (C=O stretch), $1465 \mathrm{~m}$ (H-C-H bend), $1438 \mathrm{~m}-\mathrm{s}$ (O-H bend), $1294 \mathrm{~m}$ (C-O stretch), $947 \mathrm{~m}$, broad (O-H bend), $887 \mathrm{~m}$ (H-C-S bend), $788 \mathrm{~m}-\mathrm{s}, 772 \mathrm{~m}-\mathrm{s}$ and $740 \mathrm{~m}$-s (C-S stretch) $\mathrm{cm}^{-1}$. HRMS (ESI'): $\mathrm{m} / z$ : calcd. for $\mathrm{C}_{21} \mathrm{H}_{31} \mathrm{O}_{2} \mathrm{~S}_{8} 571.0095$; found 571.0093.

$N$-[N'-(Tert-butoxycarbonyl)glycylglycylglycyl]-L-threoninol (13): The $N$-protected tripeptide Boc-(Gly) ${ }_{3}-\mathrm{OH}$ (9, Bachem) (1.05 g, $3.54 \mathrm{mmol}$ ) along with 4-nitrophenol (10, Fluka) (0.59 g, $\left.4.25 \mathrm{mmol}\right)$ were dissolved in anhydrous pyridine $(15 \mathrm{~mL})$ under argon and the solution was cooled at $0{ }^{\circ} \mathrm{C}$. Then, 1,3-dicyclohexylcarbodiimide (DCC) $(0.88 \mathrm{~g}, 4.25 \mathrm{mmol})$ was added under argon and the reaction was stirred at $0{ }^{\circ} \mathrm{C}$ for $30 \mathrm{~min}$ and then at RT overnight. After this time, the precipitate was filtered out and the solvent was removed under vacuum. The obtained residue was dissolved in toluene and concentrated to dryness under reduced pressure $(\times 3)$. The resulting 4-nitrophenyl ester 11 was used in the next step without further purification. 
The activated acid and (2R, 3R)-2-aminobutane-1,3-diol (12, L-threoninol, Sigma-Aldrich) (0.41 g, $3.89 \mathrm{mmol}$ ) were dissolved in anhydrous DMF $(15 \mathrm{~mL})$ under argon and stirred at RT for $3 \mathrm{~h}$. After this time, the solvent was removed under reduced pressure and the residue was dissolved in toluene and concentrated to dryness $(\times 3)$. The obtained residue was purified by flash chromatography on silica gel (crude adsorbed onto the silica, DCM/MeOH 100:5 $\rightarrow$ 100:15) affording the desired compound 13 as a white solid $(1.13 \mathrm{~g}, 87 \%)$. TLC in DCM/MeOH 100:10, $\mathrm{R}_{f}=0.35 .{ }^{1} \mathrm{H}-\mathrm{NMR}\left(400 \mathrm{MHz}, \mathrm{DMSO}-\mathrm{d}_{6}\right)$ $\delta$ (ppm): 8.07-8.01 (m, 2H, NH), $7.25(\mathrm{~d}, J=8.0 \mathrm{~Hz}, 1 \mathrm{H}, \mathrm{NH}), 6.95(\mathrm{t}, J=6.0 \mathrm{~Hz}, 1 \mathrm{H}, \mathrm{NH}), 4.52-4.50$ (br, 2H, OH), 3.85-3.83 (m, 1H, OH-CH-CH $\left.{ }_{3}\right), 3.71-3.68\left(\mathrm{~m}, 4 \mathrm{H}, \mathrm{NH}-\mathrm{CH}_{2}-\mathrm{CO}\right), 3.62-3.56(\mathrm{~m}, 2 \mathrm{H}$, $\left.\mathrm{NH}-\mathrm{CH}-\mathrm{CH}_{2}\right), 3.56\left(\mathrm{~d}, \mathrm{~J}=8.0 \mathrm{~Hz}, 2 \mathrm{H}, \mathrm{NH}-\mathrm{CH}_{2}-\mathrm{CO}\right), 3.44-3.37\left(\mathrm{~m}, 1 \mathrm{H}, \mathrm{OH}-\mathrm{CH}_{(A)} \mathrm{H}_{(\mathrm{B})}-\mathrm{CH}\right), 3.31-3.26$ $\left(\mathrm{m}, 1 \mathrm{H}, \mathrm{OH}-\mathrm{CH}_{(\mathrm{A})} \mathrm{H}_{(\mathrm{B})}-\mathrm{CH}\right), 1.35\left(\mathrm{~s}, 9 \mathrm{H},\left(\mathrm{CH}_{3}\right)_{3}-\mathrm{C}\right), 0.95\left(\mathrm{~d}, J=6.4 \mathrm{~Hz}, 3 \mathrm{H}, \mathrm{CH}_{3}-\mathrm{CH}-\mathrm{CH}\right) .{ }^{13} \mathrm{C}-\mathrm{NMR}$ (100 MHz, DMSO-d 6 ) $\delta$ (ppm): 170.58 (NH-CO), 169.67 (NH-CO), 169.37 (NH-CO), 156.50 (O-CO-NH), $78.83\left(\mathrm{CH}_{3}-\mathrm{C}\right), 64.88\left(\mathrm{CH}_{3}-\mathrm{CH}\right), 61.12\left(\mathrm{OH}-\mathrm{CH}_{2}-\mathrm{CH}\right), 56.43(\mathrm{NH}-\mathrm{CH}-\mathrm{CH}), 43.99\left(\mathrm{NH}-\mathrm{CH}_{2}-\mathrm{CO}\right), 42.77$ (NH-CH$-\mathrm{CO}), 42.70\left(\mathrm{NH}-\mathrm{CH}_{2}-\mathrm{CO}\right), 28.87\left(\mathrm{CH}_{3}-\mathrm{C}\right), 20.73\left(\mathrm{CH}_{3}-\mathrm{CH}\right) . \mathrm{IR}$ (solid): $v=3428 \mathrm{w}$, broad, $3294 \mathrm{~m}$, broad and $3094 \mathrm{w}$, broad (N-H and O-H stretch), $2963 \mathrm{w}$ and $2929 \mathrm{w}$ (C-H stretch), $1683 \mathrm{~m}$ and $1632 \mathrm{~s}$ (C=O stretch), $1525 \mathrm{~s}$ (N-H bending), $1481 \mathrm{w}-1394 \mathrm{w}$ (C-H bend), $1279 \mathrm{~m}, 1244 \mathrm{~s}, 1156 \mathrm{~m}, 1123 \mathrm{w}$, $1102 \mathrm{w}, 1076 \mathrm{~m}, 1048 \mathrm{~m}$ and $1025 \mathrm{~m}$ (C-O stretch or C-N stretch), $947 \mathrm{~m}$ and $857 \mathrm{~m}$ (C-H bend), $654 \mathrm{~m}$, broad (N-H out of plane bend). HRMS $\left(\mathrm{ESI}^{+}\right)$: $m / z$ : calcd. for $\mathrm{C}_{15} \mathrm{H}_{29} \mathrm{~N}_{4} \mathrm{O}_{7}\left([\mathrm{M}+\mathrm{H}]^{+}\right) 377.2036$ found 377.2031; $m / z$ : calcd. for $\mathrm{C}_{15} \mathrm{H}_{28} \mathrm{~N}_{4} \mathrm{NaO}_{7}\left([\mathrm{M}+\mathrm{Na}]^{+}\right) 399.1856$ found 399.1856.

L-Threoninol-(Gly) ${ }_{3}$-TTF derivative (14): Compound 13 ( $\left.0.87 \mathrm{~g}, 2,32 \mathrm{mmol}\right)$ was dissolved in DCM $(10 \mathrm{~mL})$ and TFA $(1 \mathrm{~mL})$ was added slowly at RT. Stirring was continued until TLC showed no remaining starting material (ca. 1-1.5 h) and the mixture was concentrated to dryness under reduced pressure. The obtained residue was dissolved in toluene and concentrated to dryness under reduced pressure. This process was repeated three times to remove traces of TFA to yield the TFA salt of the deprotected amino compound (colorless oil). This crude TFA salt was dried in vacuo and used in the next step without purification.

$\left\{\left[4^{\prime}, 5,5^{\prime}\right.\right.$-Tris(butylsulfanyl)-2,2'-bis-1,3-dithiol-4-yl]sulfanyl $\}$ propanoic acid $(8,0.95 \mathrm{~g}, 1.66 \mathrm{mmol})$ along with $\mathrm{N}$-hydroxysuccinimide (NHS) (Sigma-Aldrich) $(0.21 \mathrm{~g}, 1.83 \mathrm{mmol})$ were dissolved in anhydrous THF $(40 \mathrm{~mL})$ under argon and the solution was cooled at $0{ }^{\circ} \mathrm{C}$. Then, DCC $(0.38 \mathrm{~g}, 1.83 \mathrm{mmol})$ was added under argon and the reaction was stirred at $0^{\circ} \mathrm{C}$ for $30 \mathrm{~min}$ and at RT overnight. The precipitate was filtered out and the solvent was removed under reduced pressure. The resulting $N$-hydroxysuccinimide ester was used in the next step without further purification. The active ester was dissolved in anhydrous DMF (30 mL). The TFA salt of the deprotected amino compound was dissolved in DMF ( $30 \mathrm{~mL})$ and $\mathrm{N}, \mathrm{N}$-diisopropylethylamine (DIEA) $(405 \mu \mathrm{L}, 2.32 \mathrm{mmol})$ was added. Then, the solution of the active ester was added under argon and the mixture was allowed to react at RT for $30 \mathrm{~min}$. The solvent was removed under reduced pressure and the residue was dissolved in toluene and concentrated to dryness $(\times 3)$. The crude compound was washed with hexane $(5 \times 70 \mathrm{~mL})$ and with diethyl ether $(5 \times 70 \mathrm{~mL})$. The residue was dissolved in DCM $(300 \mathrm{~mL})$ and the organic phase was washed with $5 \%$ aqueous $\mathrm{NaHCO}_{3}(2 \times 75 \mathrm{~mL})$ and saturated aqueous $\mathrm{NaCl}(75 \mathrm{~mL})$, dried over anhydrous $\mathrm{MgSO}_{4}$, and concentrated to dryness under reduced pressure. The crude residue was purified by chromatography on silica gel (DCM/MeOH 100:0.5 $\rightarrow 90: 10)$ obtaining a reddish solid (868 $\mathrm{mg}, 62 \%$ ). TLC (DCM/MeOH 100:1) $\mathrm{R}_{f}=0.10 .{ }^{1} \mathrm{H}-\mathrm{NMR}\left(400 \mathrm{MHz}, \mathrm{CD}_{3} \mathrm{OD}\right) \delta$ (ppm): 7.83-7.52 (NH zone), 3.98-3.95 (m, 1H, OH-CH-CH $\left.\mathrm{CH}_{3}\right), 3.91-3.69\left(\mathrm{~m}, 6 \mathrm{H}, \mathrm{NH}-\mathrm{CH}_{2}-\mathrm{CO}\right), 3.82-3.79\left(\mathrm{~m}, 1 \mathrm{H}, \mathrm{NH}-\mathrm{CH}-\mathrm{CH}_{2}\right)$, 3.66-3.62 (m, 1H, OH-CH $\left.\mathrm{CH}_{(A)} \mathrm{H}_{(\mathrm{B})}-\mathrm{CH}\right), 3.60-3.55\left(\mathrm{~m}, 1 \mathrm{H}, \mathrm{OH}_{-} \mathrm{CH}_{(\mathrm{A})} \mathrm{H}_{(B)}-\mathrm{CH}\right), 3.09(\mathrm{t}, J=7.2 \mathrm{~Hz}, 2 \mathrm{H}$, $\left.\mathrm{SCH}_{2}-\mathrm{CH}_{2}-\mathrm{CONH}\right), 2.87-2.81\left(\mathrm{~m}, 6 \mathrm{H}, \mathrm{SCH}_{2}-\mathrm{CH}_{2}-\mathrm{CH}_{2}-\mathrm{CH}_{3}\right), 2.64\left(\mathrm{t}, J=7.2 \mathrm{~Hz}, 2 \mathrm{H}, \mathrm{SCH}_{2}-\mathrm{CH}_{2}-\mathrm{CONH}\right)$, 1.64-1.56 (m, 6H, C-SCH $\left.-\mathrm{CH}_{2}-\mathrm{CH}_{2}-\mathrm{CH}_{3}\right), 1.49-1.40\left(\mathrm{~m}, 6 \mathrm{H}, \mathrm{C}-\mathrm{SCH}_{2}-\mathrm{CH}_{2}-\mathrm{CH}_{2}-\mathrm{CH}_{3}\right), 1.13(\mathrm{~d}, J=6.4 \mathrm{~Hz}$, $\left.3 \mathrm{H}, \mathrm{CH}_{3}-\mathrm{CH}-\mathrm{CH}\right), 0.92\left(\mathrm{t}, 9 \mathrm{H}, J=7.2 \mathrm{~Hz}, \mathrm{SCH}_{2}-\mathrm{CH}_{2}-\mathrm{CH}_{2}-\mathrm{CH}_{3}\right) .{ }^{13} \mathrm{C}-\mathrm{NMR}\left(100 \mathrm{MHz}, \mathrm{CD}_{3} \mathrm{OD}\right) \delta(\mathrm{ppm})$ : $172.71,171.21,170.82$ and 170.44 (NH-CO), 129.50, 127.78, 127.10 and $126.18\left(-\mathrm{CH}_{2}\right.$-S-C-S-), 110.15 and $109.49\left(\mathrm{~S}_{2} \mathrm{C}=\mathrm{CS}_{2}\right), 65.80\left(\mathrm{CH}_{3}-\mathrm{CH}\right), 61.35\left(\mathrm{OH}-\mathrm{CH}_{2}-\mathrm{CH}\right), 56.34(\mathrm{NH}-\mathrm{CH}-\mathrm{CH}), 42.49,42.43$ and 42.17 (NH-CH$-\mathrm{CO}), 35.52,35.45,35.40$ and $35.38\left(\mathrm{~S}-\mathrm{CH}_{2}-\right.$ and $\left.\mathrm{SCH}_{2}-\mathrm{CH}_{2}-\mathrm{CONH}\right), 31.59,31.56$ and 31.55 
(S- $\left.\mathrm{CH}_{2}-\mathrm{CH}_{2}\right), 31.02\left(\mathrm{SCH}_{2}-\mathrm{CH}_{2}-\mathrm{CONH}\right), 21.16$ and $21.14\left(\mathrm{~S}-\mathrm{CH}_{2}-\mathrm{CH}_{2}-\mathrm{CH}_{2}-\right), 18.92\left(\mathrm{CH}_{3}-\mathrm{CH}\right), 12.54$ and $12.51\left(\mathrm{~S}-\mathrm{CH}_{2}-\mathrm{CH}_{2}-\mathrm{CH}_{2}-\mathrm{CH}_{3}\right)$. IR (solid): $v=3280 \mathrm{~m}$, broad and $3086 \mathrm{w}$, broad $(\mathrm{O}-\mathrm{H}$ and N-H stretch), $2955 \mathrm{~m}-\mathrm{w}, 2926 \mathrm{~m}-\mathrm{w}$ and $2869 \mathrm{w}$ (C-H stretch), $1642 \mathrm{~s}$ (C=O stretch), $1553 \mathrm{~m}-\mathrm{s}$ (N-H bend), $1456 \mathrm{~m}-\mathrm{w}, 1417 \mathrm{~m}-\mathrm{w}$ and $1376 \mathrm{~m}-\mathrm{w}$ (C-H bend or O-H bend or H-C-H bend), $1249 \mathrm{~m}, 1099 \mathrm{~m}$ and $1028 \mathrm{~m}$ (C-O stretch and N-H stretch), $886 \mathrm{w}$ (H-C-S bend or C-H bend), $771 \mathrm{~m}$ (C-S stretch), $684 \mathrm{~m}$, broad (N-H out of plane). HRMS (ESI $\left.{ }^{+}\right): m / z$ : calcd for $\mathrm{C}_{31} \mathrm{H}_{52} \mathrm{~N}_{4} \mathrm{O}_{2} \mathrm{~S}_{8}\left([\mathrm{M}+\mathrm{H}]^{+}\right) 831.1574$ found 831.1613; $m / z$ : calcd for $\mathrm{C}_{31} \mathrm{H}_{52} \mathrm{~N}_{4} \mathrm{NaO}_{2} \mathrm{~S}_{8}\left([\mathrm{M}+\mathrm{Na}]^{+}\right) 853.1394$ found 853.1416.

\subsection{Preparation and Characterization of Gel Materials}

Anhydrous solvents used for gelation tests were purchased from commercial suppliers. Gelation tests were carried out in screw-capped glass vials $(4 \mathrm{~cm}$ length $\times 1 \mathrm{~cm}$ diameter) having a specific amount of the TTF derivative $\mathbf{1 4}$ and the desired solvent $(1 \mathrm{~mL})$. The mixture was heated with a standard heat gun until complete dissolution. Then, the clear solution was allowed to cool down to RT. The material was initially classified as gel if it did not flow by turning the vial upside-down. The viscoelastic nature was further confirmed by rheology of a model system.

Critical gelation concentration (CGC) corresponds to the minimum gelator concentration required for gelation. The values were obtained by continuously adding aliquots of solvent $(0.02-0.1 \mathrm{~mL})$ into vials having the TTF derivative $\mathbf{1 4}$ and performing either the heating or cooling until no gelation was observed. The waiting time used to define the state of the material was $\sim 12 \mathrm{~h}$. Concentrations above $200 \mathrm{~g} / \mathrm{L}$ were not tested.

Thermal gel-to-sol transition temperature $\left(T_{\text {gel }}\right)$ values were determined using a calibrated thermoblock at $1{ }^{\circ} \mathrm{C} / 5 \mathrm{~min}$ (Figure S1). The temperature at which the bulk gel started to break was defined as $T_{\text {gel }}$. Due to potential effects of thermal history and hysteresis [75], the apparatus has been previously calibrated with samples measured by differential scanning calorimetry (DSC) [76].

Rheological measurements were performed with an AR 2000 Advanced rheometer (TA Instruments, New Castle, DE, USA). Conditions: $1000 \mathrm{~mm}$ gap, torque $=5 \times 10^{-4} \mathrm{~N} / \mathrm{m}, 25^{\circ} \mathrm{C}$, plain-plate geometry (20 mm, stainless steel), sample volume $=2 \mathrm{~mL}$. Dynamic strain sweep (DSS) measurements were performed between 0.01 and $100 \%$ strain. For dynamic frequency sweep (DFS) measurements, frequency was varied from 0.1 to $10 \mathrm{~Hz}$ at $0.1 \%$ strain. Finally, dynamic time sweep (DTS) measurements were carried out within the linear regime at $0.1 \%$ strain and $1 \mathrm{~Hz}$ frequency.

FT-IR spectra were obtained at RT with a Cary 630 FTIR spectrometer (Agilent Technologies, Santa Clara, CA, USA) equipped with an attenuated total reflection (ATR) accessory (32 scans, spectral resolution $=8 \mathrm{~cm}^{-1}$ ).

Field emission scanning electron microscopy (FE-SEM) of xerogels was carried out with a Zeiss Merlin, Field Emission Scanning Electron Microscope (accelerating voltage $=10 \mathrm{kV}$ ). Xerogels, prepared by freeze-drying the gels, were placed on top of a tin plate and shielded with $\mathrm{Pt}$ ( $40 \mathrm{~mA}, 30-60 \mathrm{~s}$; film thickness $=5-10 \mathrm{~nm}$ ). Images were by Servicio General de Apoyo a la Investigación-SAI (University of Zaragoza).

Images under polarized light were obtained using a Wild Makroskop M420 optical microscope equipped with a Canon Power shot A640 camera.

UV-vis spectra were obtained with an Ocean Optics, Flame spectrometer with a DH-2000-BAL light source or on a Varian Cary $50 \mathrm{UV}$ spectrophotometer. Quartz-glass cuvettes of $0.5 \mathrm{~cm}$ thickness were used.

Iodine doping was achieved by exposing the xerogel to $\mathrm{I}_{2}$ vapor for circa $120 \mathrm{~min}$ in a sealed glass beaker with $I_{2}$ crystals. 


\section{Results and Discussion}

\subsection{Synthesis of TTF-Triglycyl Derivative}

The synthesis of the TTF-triglycyl derivative 14 was achieved by assembling the L-threoninol, and triglycine units with the TTF carboxylic derivative 8 (Scheme 1). First, compound 8 was prepared following the procedure described in the literature [10] with slight modifications. The first step consisted in the synthesis of 4,5-bis-(butylthio)-1,3-dithiole-2-thione (3) by alkylation of the zinc complex of bis(1,3-dithiole-2-thione-4,5-dithiolate) tetrabutylammonium salt (1) with 1-bromobutane (2) as described for similar compounds by Simonsen and co-workers [77]. Phosphite-induced coupling of compounds 3 and 4 [77] gave the symmetric TTF derivative 5 in good yield (64\%). Selective sequential deprotection of one 2-cyanoethyl group followed by alkylation with 1-bromobutane (2) gave the TTF derivative 6 in very good yield (89\%). A second round of sequential deprotection of the second 2-cyanoethyl group followed by alkylation with 3-bromopropionic acid (7) [78] gave the desired TTF carboxylic derivative 8 in 91\% yield.
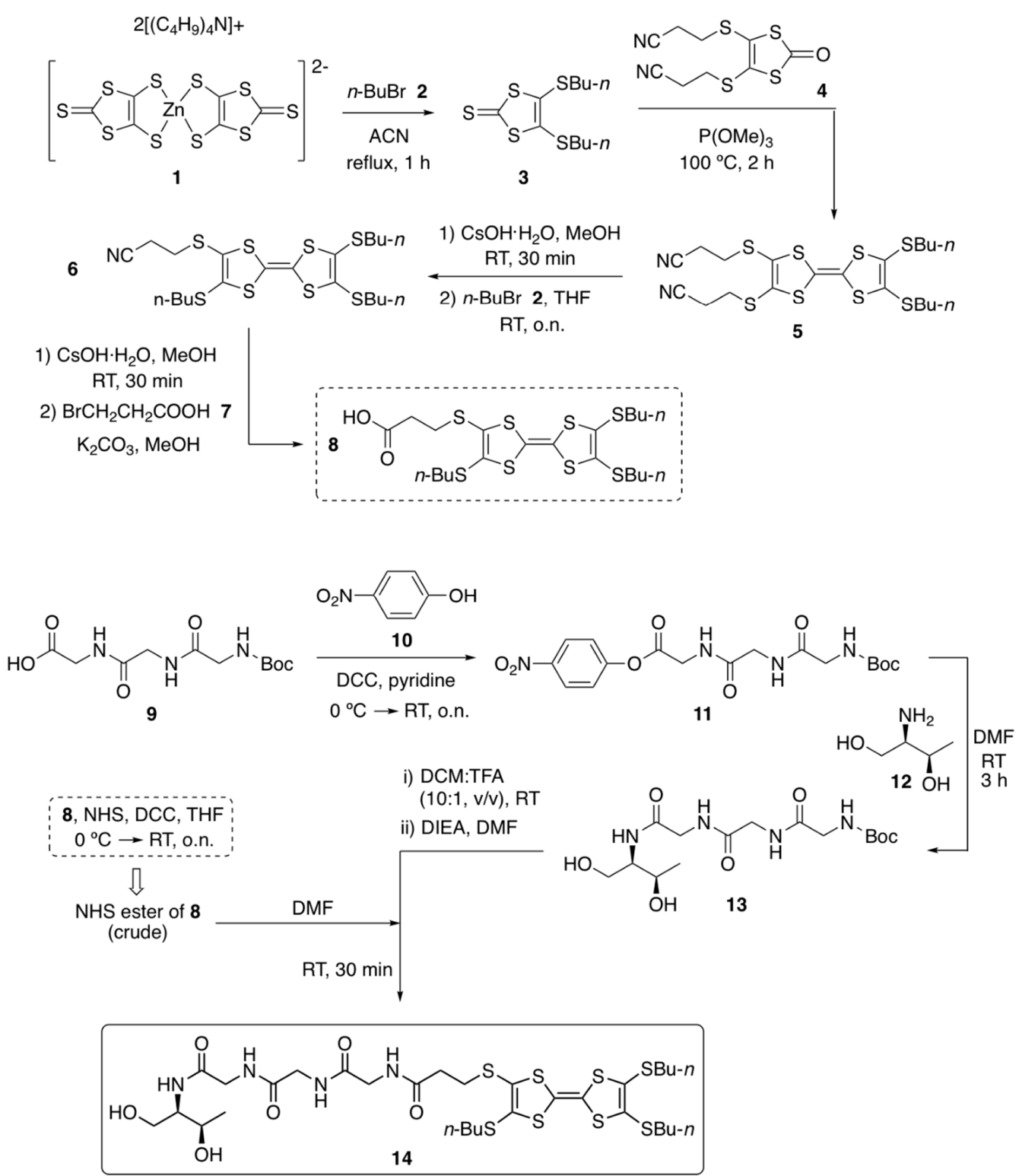

Scheme 1. Synthesis of TTF-triglycyl derivative 14. 
Then Boc-protected triglycine 9 was activated with DCC and 4-nitrophenol (10). Then, the obtained nitrophenyl active ester 11 was reacted with L-threoninol (12) yielding the $t$-butoxycarbonyl (Boc)-protected triglycine-L-threoninol derivative 13. This compound was treated with a TFA solution in DCM to remove the Boc-amino protecting group yielding the corresponding L-threoninol-triglycine trifluoroacetate salt that was subsequently used without purification for the coupling with compound 8 in the presence of Hünig's base. This reaction was done via classical activation of the carboxyl group with DCC and NHS, affording the desired TTF-based gelator $\mathbf{1 4}$ in $24 \%$ (isolated yield).

\subsection{Gelation Properties}

The gelation ability of TTF-triglycyl derivative $\mathbf{1 4}$ was studied for a number of anhydrous solvents of different nature (i.e., apolar, polar aprotic, polar protic) using the standard heating-cooling treatment. Materials that did flow upon inversion of the vial upside-down were initially classified as gels. One of the gels was used later as a model example to demonstrate its viscoelastic nature by oscillatory rheological measurements (see below). Compound $\mathbf{1 4}$ was found to be soluble in methanol, ethanol, isopropanol, dimethylformamide, dimethyl sulfoxide, and tetrahydrofuran, whereas it resulted insoluble in diethyl ether, acetonitrile, $n$-hexane, and cyclohexane. In contrast, opaque gels were obtained in 10 solvents at concentrations varying between $5 \pm 1$ and $50 \pm 10 \mathrm{~g} / \mathrm{L}$ (Table 1).

Table 1. Gelation ability of TTF-triglycyl derivative 14, critical gelation concentration (CGC), gelation time, and gel-to-sol transition temperature $\left(T_{\text {gel }}\right){ }^{1}$

\begin{tabular}{cccc}
\hline Solvent $^{2}$ & CGC $(\mathbf{g} / \mathrm{L})$ & Gelation Time $(\mathbf{m i n})$ & $\boldsymbol{T}_{\text {gel }}\left({ }^{\circ} \mathbf{C}\right)$ \\
\hline Acetone & $40 \pm 10$ & $60 \pm 10$ & $36 \pm 3^{4}$ \\
Benzene & $6 \pm 1$ & $78 \pm 5$ & $37 \pm 2$ \\
Benzonitrile & $35 \pm 10$ & $55 \pm 5$ & $42 \pm 2$ \\
Chlorobenzene & $9 \pm 1$ & $78 \pm 5$ & $38 \pm 2$ \\
Chloroform & $18 \pm 2$ & $10 \pm 2$ & $50 \pm 3$ \\
Dichloromethane & $29 \pm 2$ & $10 \pm 2$ & $49 \pm 2$ \\
1,4-Dioxane & $50 \pm 10$ & $60 \pm 10$ & $51 \pm 3$ \\
Ethyl acetate & $5 \pm 1$ & $10 \pm 2$ & $47 \pm 2$ \\
Toluene & $9 \pm 1$ & $90 \pm 10$ & $41 \pm 2$ \\
Xylene $^{3}$ & $8 \pm 1$ & $90 \pm 10$ & $46 \pm 2$ \\
\hline
\end{tabular}

\footnotetext{
${ }^{1}$ Gels were obtained upon a heating-cooling cycle (see Experimental Section). The use of anhydrous solvents was found to be very critical to obtain the lowest possible critical gelation concentration (CGC) values. In general, the use non-anhydrous solvents either inhibited the gelation or raised the CGC up to 3-4 times in comparison to anhydrous solvents. Error values were calculated from three randomized experiments. ${ }^{2}$ Solvent volume $=1 \mathrm{~mL}$. ${ }^{3}$ Xylene was used as mixture of isomers. ${ }^{4}$ Partial gel formation was observed. In this case, $T_{\text {gel }}$ value corresponds to the isolated gelled portion.
}

These gels remained stable for at least two months when stored in sealed vials at RT. Their color varied from bright orange to dark orange-brown depending on the solvent (Figure 2a). The supramolecular gels showed typical thermoreversibility (Figure 2b), and their opaque appearance suggested the presence of aggregates larger than the wavelength of visible light $(\lambda=380-780 \mathrm{~nm})$, which was in agreement with electron microscopy (see below). Further investigations were carried out using only some selected gels as representative materials.

As mentioned in the introduction, it is well established that the redox TTF core in this type

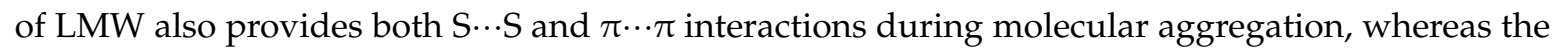
peptide chain drives molecular aggregation via hydrogen bonding [73,74]. Comparison of Fourier transform infrared (FT-IR) spectra of solid TTF derivative $\mathbf{1 4}$ with that of the xerogel (i.e., prepared by freeze-drying the corresponding organogel) and $\mathbf{1 4}$ in solution (i.e., below the CGC) showed only very small frequency shifts (i.e., red-shift $\Delta v \sim 5 \mathrm{~cm}^{-1}$ ) for characteristic bands such as $\mathrm{C}=\mathrm{O}$ stretching $\left(\sim 1641 \mathrm{~cm}^{-1}\right), \mathrm{N}-\mathrm{H}$ amide I $\left(\mathrm{br} \sim 3280 \mathrm{~cm}^{-1}\right)$, and N-H amide II (bending vibration) $\left(\sim 1553 \mathrm{~cm}^{-1}\right)$ (Figure S2). These values suggest that $\mathbf{1 4}$ may also be aggregated in the solid state and in solution via 
similar intermolecular hydrogen-bonding pattern between amide groups, most likely in the parallel $\beta$-sheet conformation [79], as well as van der Waals interactions between the alkyl chains.

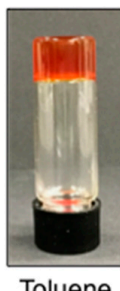

Toluene

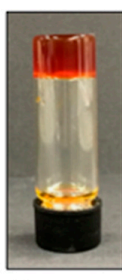

Benzene

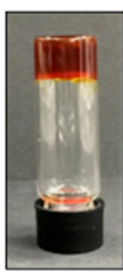

$\mathrm{PhCl}$

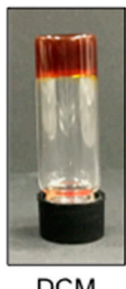

DCM

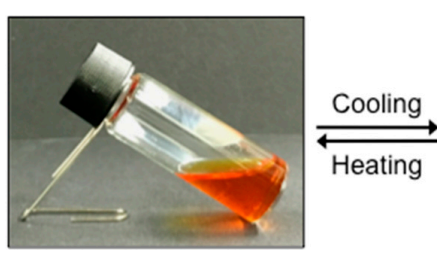

(b)

Figure 2. (a) Photographs of upside-down vials having selected gels made of $\mathbf{1 4}$ in toluene, benzene, chlorobenzene $(\mathrm{PhCl})$, and dichloromethane (DCM) at the CGC (see Table 1); (b) illustration of the thermal sol-gel transition of the gel made of $\mathbf{1 4}$ in toluene at the CGC.

\subsection{Characterization of Organogels}

In general, relatively low gel-to-sol transition temperatures $\left(T_{\text {gel }}\right)$ were determined for all gels ranging from 36 to $51{ }^{\circ} \mathrm{C}( \pm 3)$ (Table 1). As typically observed with most supramolecular gels, $T_{\text {gel }}$ gradually increased with increasing gelator concentration due to the generation of denser networks (Figure 3). Taking the gels prepared in toluene and ethyl acetate as representative systems, a plateau region was reached before the gels collapsed into partial and inhomogeneous gels that constantly lose solvent over time. The increment of the $T_{\text {gel }}$ until the plateau region was $\sim 39^{\circ} \mathrm{C}$ for toluene and $\sim 25{ }^{\circ} \mathrm{C}$ for ethyl acetate with respect to the initial values obtained at their CGC. Linear Ln-Ln plot (Figure 3 , inset) using the percentage increases of $T_{\text {gel }}$ showed that the percentage increment of $T_{\text {gel }}$ was $\sim 1.1$-fold higher for the gel made in ethyl acetate. Further research is necessary to understand the reasons behind such differences.

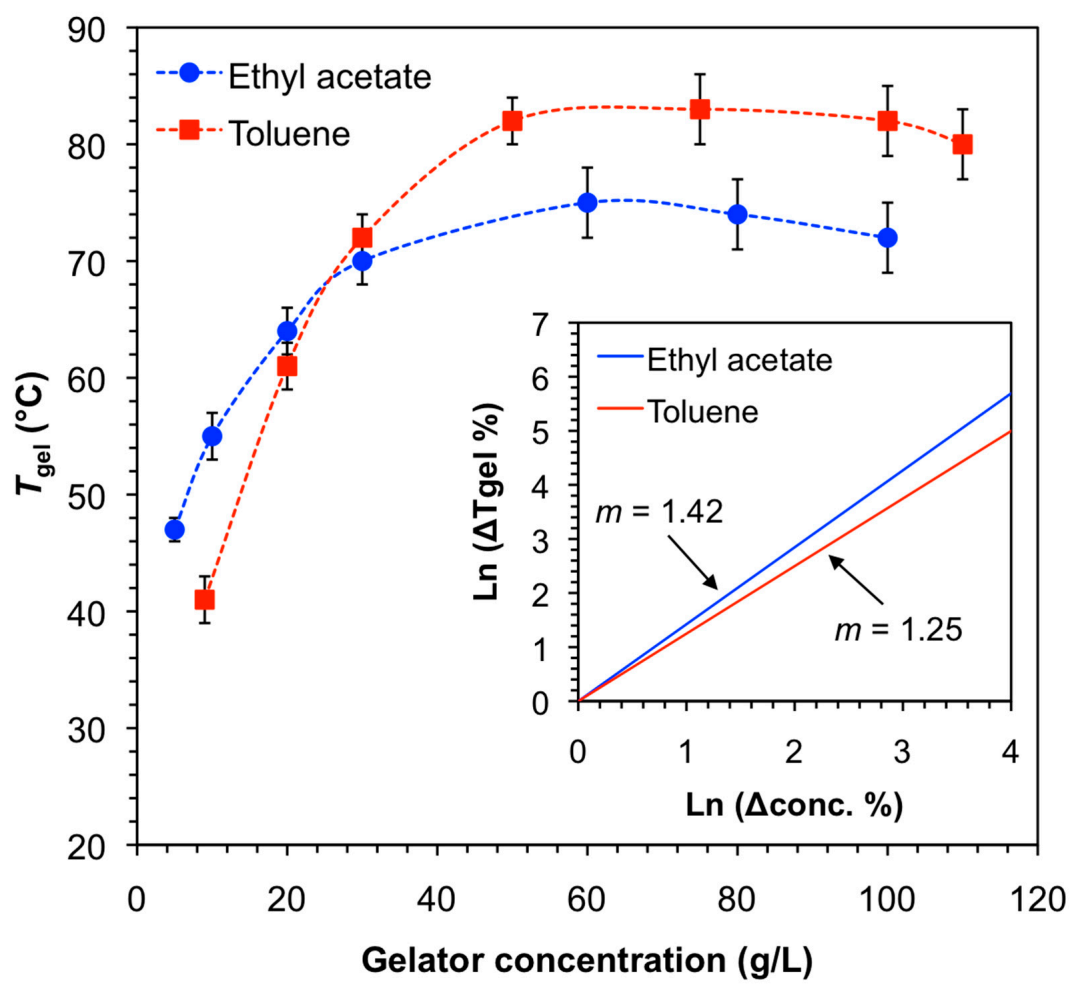

Figure 3. Variation of $T_{\text {gel }}$ with increasing gelator concentration for the gels made in toluene and ethyl acetate. Inset: Normalized Ln-Ln plot of $T_{\text {gel }}$ percentage increases. 
Dynamic rheological experiments (Figure 4) for the model gel made of $\mathbf{1 4}$ in toluene confirmed its viscoelastic nature. Within the linear regime established by dynamic frequency sweep (DFS) and dynamic strain sweep (DFS) measurements, the storage modulus $G^{\prime \prime}$ was found to be one order of magnitude higher than the loss modulus $G^{\prime \prime}$ with low frequency dependency (i.e., $G^{\prime} \approx 8.9 \pm 0.5 \mathrm{kPa}$, $G^{\prime \prime} \approx 0.75 \pm 0.1 \mathrm{kPa}$ ) (Figure 3a). Moreover, the gels were brittle in nature, which was confirmed by its destruction at low frequency and $\sim 7 \%$ of strain (Figure $4 a$ ). Finally, dynamic time sweep (DTS) measurements at $0.1 \%$ strain and $1 \mathrm{~Hz}$ frequency confirmed the stability of the gel over time at RT (Figure 4b).

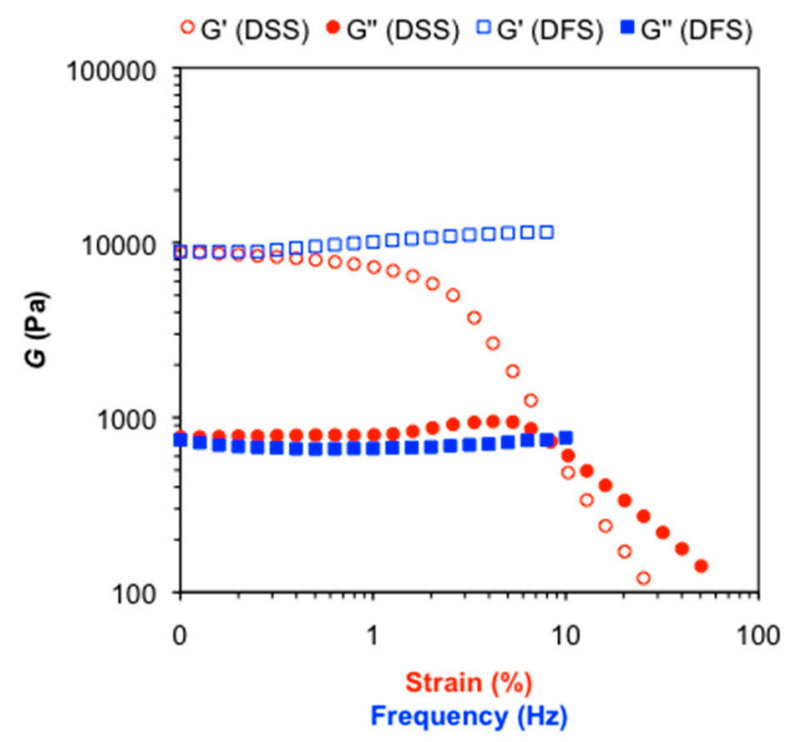

(a)

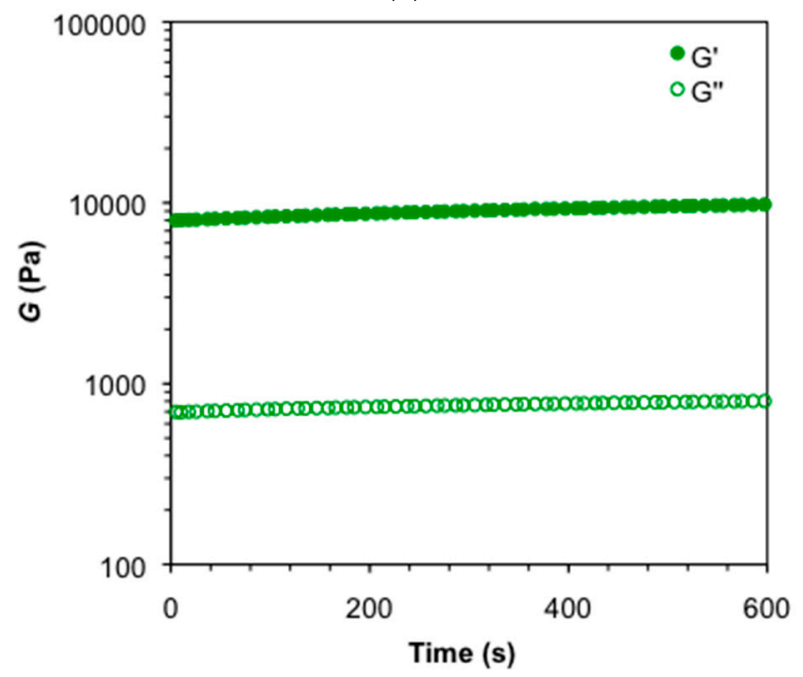

(b)

Figure 4. (a) Dynamic frequency sweep (DFS), dynamic strain sweep (DSS), and (b) dynamic time sweep (DTS) measurements for the model gel made of $\mathbf{1 4}$ in toluene $(9 \mathrm{~g} / \mathrm{L})$. The $\tan \delta$ (i.e., $G^{\prime \prime} / G^{\prime}$, damping coefficient) was reproducible in random experiments.

Morphological studies of selected organogels were conducted by field emission scanning electron microscopy (FE-SEM) of the corresponding xerogels (Figure 5). In general, fibrillar networks with high aspect ratio were observed for several organogels made of $\mathbf{1 4}$. As observed with other supramolecular self-assembled gels, interactions between solvent-aggregate, solvent-gelator, and gelator-gelator molecules are also regulated by the solvent nature and have a major effect on the microstructure of 
the materials. For instance, dense and entangled leaf-like structures were observed for the material obtained in ethyl acetate (Figure 5a), whereas the samples prepared in benzonitrile showed a smooth surface with fibrillar structures of $\sim 0.5-1 \mu \mathrm{m}$ in diameter (Figure $5 \mathrm{~b}$ ). A highly dense and porous network made of fibers up to $\sim 1 \mu \mathrm{m}$ in diameter was observed for the gel made in 1,4-dioxane (Figure 5c). Surfaces made of smaller fibers of $\sim 50-100 \mathrm{~nm}$ in diameter resembling a mountainous valley were observed for the specimens prepared in toluene (Figure 5d). However, fibrillar-globular structures with diameters between $\sim 100$ and $500 \mathrm{~nm}$ were distinguished when the solvent used for the preparation of the gel was dichloromethane (Figure 5e). Although we systematically took pictures of the bulk samples at different magnifications and locations on the grid in order to identify possible artifacts in the microstructures, it should be considered that such artifacts can be produced during the preparation and visualization of the samples and, therefore, the conclusions derived from these images should not be oversold. Furthermore, the typical anisotropic growth in this type of materials, suggesting well-ordered molecular packing, is also evidenced by the observation of birefringent domains under polarized light (Figure 5f), which is important for optical applications [80].

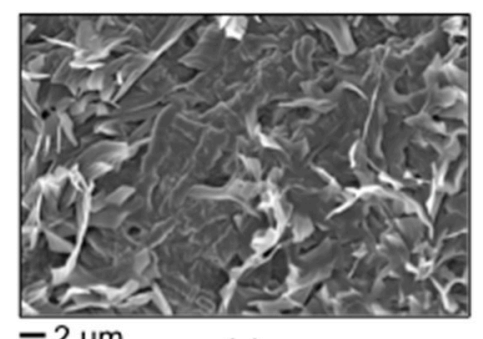

(a)

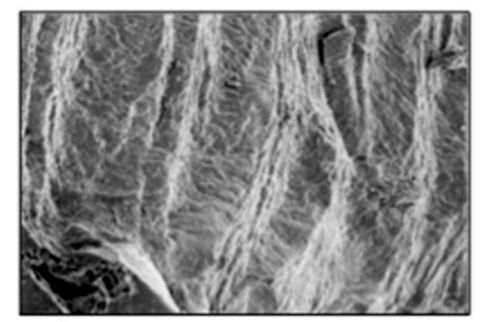

$-2 \mu \mathrm{m}$

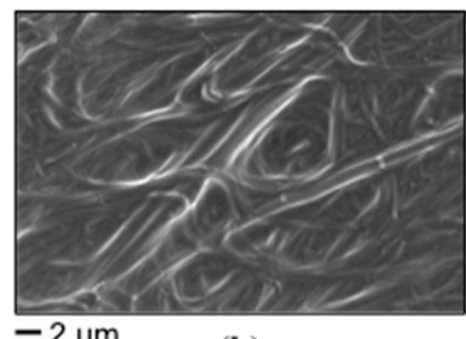

(b)

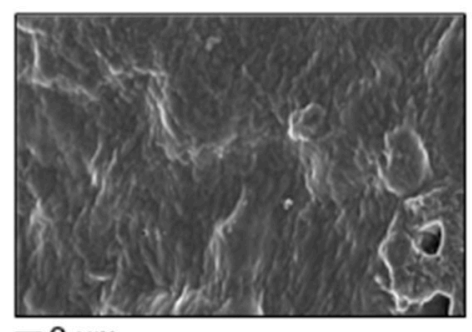

(e)

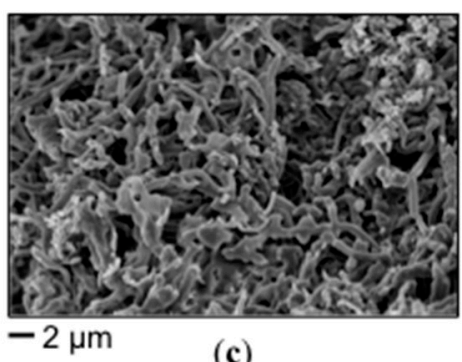

(c)

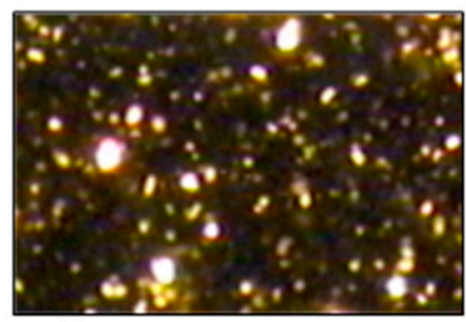

(f)

Figure 5. Representative FE-SEM photographs of xerogels prepared by freeze-drying the organogels made of 14 in (a) ethyl acetate ( $5 \mathrm{~g} / \mathrm{L})$; (b) benzonitrile ( $35 \mathrm{~g} / \mathrm{L})$; (c) 1,4-dioxane (50 g/L); (d) toluene $(9 \mathrm{~g} / \mathrm{L})$; (e) dichloromethane $(29 \mathrm{~g} / \mathrm{L})$; (f) birefringent domains visualized under polarized light for the xerogel derived from the gel made of $\mathbf{1 4}$ in dichloromethane $(29 \mathrm{~g} / \mathrm{L})$.

\subsection{Effect of Iodine-Doping}

Iodine-doping of the fibrous xerogel derived from a model gel made in DCM confirmed the oxidation of the TTF moiety in the gelator preserving the self-assembled network structure. UV-vis-NIR spectrum of the xerogel after exposure to $\mathrm{I}_{2}$ vapor showed new absorption bands centered at approximately 360, 500, and $850 \mathrm{~nm}$ (Figure 6). The absorption bands at 360 and $500 \mathrm{~nm}$ are typically ascribed to intramolecular electronic transitions involving the TTF cation radical, whereas the broad band located at $850 \mathrm{~nm}$ indicates the formation of a full CT state between cation radicals of self-stacked TTF units (i.e., $\mathrm{TTF}^{+} \mathrm{I}^{-}$). The increase in the absorbance above $600 \mathrm{~nm}$ is in agreement with the formation of a partial mixed-valence CT state between TTF-containing neutral and cation radicals (i.e., $(\mathrm{TTF})(\mathrm{I})_{\mathrm{n}}$ with $\left.\mathrm{n}<1\right)[58,73]$. Unfortunately, the intermolecular hydrogen-bonded network seemed to be altered during the oxidation as shown by visible changes in the intensity and position of the IR absorption bands associated to $\mathrm{N}-\mathrm{H}$ and $\mathrm{C}=\mathrm{O}$ stretching vibrations of the amides (Figure $\mathrm{S} 3$ ). Unfortunately, although iodine can create the necessary unfilled states required for conduction, 
the instability of the fibrillar network prevented us from obtaining reproducible conductivity values. As observed with other similar gels, preliminary experiments also showed a gel-to-sol transition after exposure of the wet gel to iodine vapors.

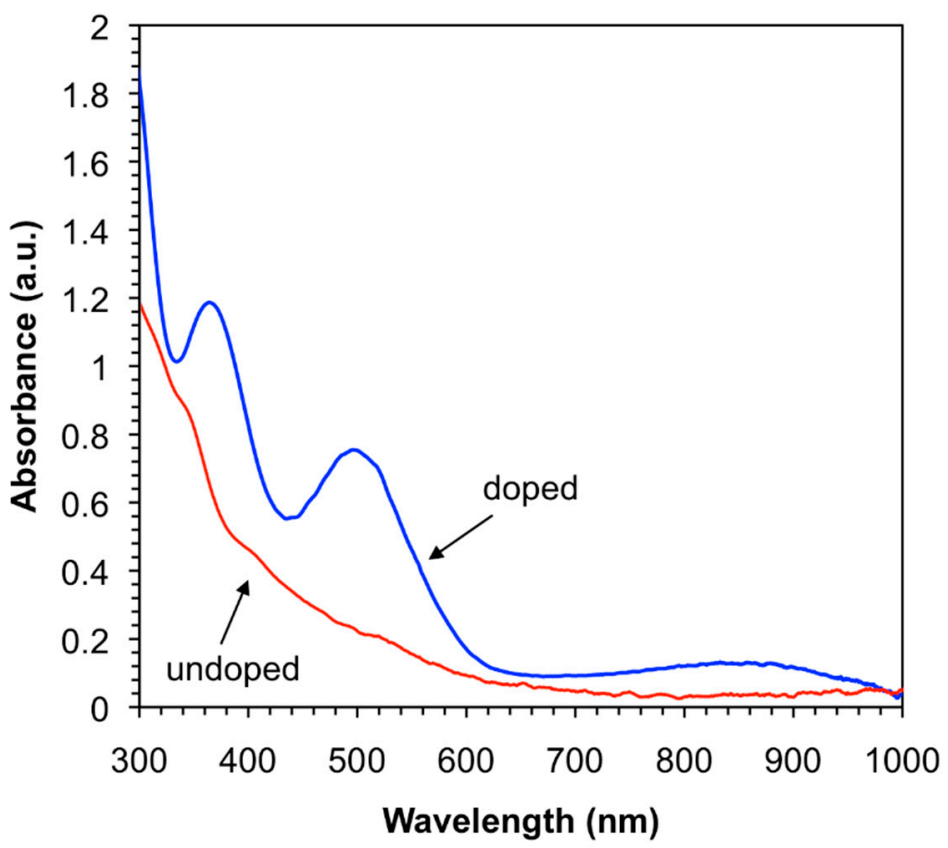

Figure 6. UV-vis-NIR spectra before and after doping with $\mathrm{I}_{2}$ the xerogel prepared from the organogel made of 14 in DCM $(29 \mathrm{~g} / \mathrm{L})$.

\section{Conclusions}

In conclusion, TTF-triglycyl derivative $\mathbf{1 4}$ was synthesized and fully characterized by standard techniques. This compound was found to act as a LMW gelator for a series of organic solvents after a heating-cooling cycle. Therefore, the presence of aromatic rings on the peptide linked to the TTF unit is not a requirement for the formation of supramolecular gels using TTF-peptide conjugates. The critical gelation concentrations ranged from $\sim 5$ to $50 \mathrm{~g} / \mathrm{L}$, and the thermal gel-to-sol transition temperatures varied from $\sim 36$ to $51^{\circ} \mathrm{C}$. FE-SEM imaging of the xerogels, prepared by freeze-drying the organogels, showed fibrillar microstructures with distinctive features depending on the solvent used to prepare the gels. Moreover, the viscoelastic and brittle nature of a model gel system was also supported by dynamic rheological experiments. Finally, UV-vis-NIR analysis of a model xerogel confirmed the oxidation of the TTF unit upon exposure to $\mathrm{I}_{2}$ vapor. Nevertheless, FT-IR spectroscopy showed that the oxidation was accompanied with concurrent alteration of the intermolecular hydrogen-bonded network.

Supplementary Materials: The following are available online at http:/ /www.mdpi.com/2076-3417/8/5/671/s1, NMR spectra, FT-IR spectra, Figure S1: Thermoblock used for $T_{\text {gel }}$ determinations. (A) Front view of the set-up. (B) Top view of the set-up during a typical experiment. The set-up was previously calibrated with literature data for known compounds, Figure S2: FT-IR spectra of solid 14, 14 dissolved in DCM, and xerogel, i.e., prepared by freeze-drying the organogel made of 14 in DCM (29 g/L), Figure S3: FT-IR spectra of the xerogel, obtained from the corresponding organogel made of 14 in DCM $(29 \mathrm{~g} / \mathrm{L})$, before and after iodine-doping.

Author Contributions: Pérez-Rentero Sónia carried out the synthesis and characterization of all compounds, and observed for the first time the aggregation tendency of the gelator. Häring Marleen, Saldías César, and Díaz Díaz David carried out the rest of the experiments. Díaz Díaz David and Eritja Ramon directed the project. All authors participated in writing the manuscript.

Acknowledgments: This work was supported by the Ministerio de Economía, Industria y Competitividad (CTQ2014-52588-R, CTQ2017-84415-R), Generalitat de Catalunya (2014/SGR/624), the Instituto de Salud Carlos III (ISCIII) (CB06_01_0019), and Universität Regensburg. CIBER-BBN is an initiative funded by the VI National R+D+i Plan 2008-2011, Iniciativa Ingenio 2010, Consolider Program, CIBER actions and financed by ISCIII with 
assistance from the European Regional Development Fund. We thank Ivo Starý, Jiří Janoušek, Martin Bělohradský, and Irena G. Stará (IOCB, Academy of Sciences of the Czech Republic) for their help in the synthesis of the TTF derivative; Judith Mayr (Universität Regensburg) for preliminary gelation tests; and Alex Abramov (Universität Regensburg) for assistance with UV/IR measurements. David Díaz Díaz thanks Deutsche Forschungsgemeinschaft (DFG) for the Heisenberg Professorship Award.

Conflicts of Interest: The authors declare no conflict of interest.

\section{References}

1. Hornum, M.; Kumar, P.; Podsiadly, P.; Nielsen, P. Increasing the stability of DNA:RNA duplexes by introducing stacking phenyl-substituted pyrazole, furan, and triazole moieties in the major groove. J. Org. Chem. 2015, 80, 9592-9602. [CrossRef] [PubMed]

2. Hrdlicka, P.J.; Karmakar, S. 25 years and still going strong: 2'-O-(pyren-1-yl)methylribonucleotides-Versatile building blocks for applications in molecular biology, diagnostics and materials science. Org. Biomol. Chem. 2017, 15, 9760-9774. [CrossRef] [PubMed]

3. Krasheninina, O.A.; Novopashina, D.S.; Apartsin, E.K.; Venyaminova, A.G. Recent advances in nucleic acid targeting probes and supramolecular constructs based on pyrene-modified oligonucleotides. Molecules 2017, 22, 2108. [CrossRef] [PubMed]

4. Dogan, Z.; Paulini, R.; Stütz, J.A.R.; Narayanan, S.; Richert, C. 5-Tethered stilbene derivatives as fidelity- and affinity-enhancing modulators of DNA duplex stability. J. Am. Chem. Soc. 2004, 126, 4762-4763. [CrossRef] [PubMed]

5. Zahn, A.; Leumann, C.J. Recognition properties of donor- and acceptor-modified biphenyl-DNA. Chem. Eur. J. 2008, 14, 1087-1094. [CrossRef] [PubMed]

6. Aviñó, A.; Mazzini, S.; Ferreira, R.; Eritja, R. Synthesis and structural properties of oligonucleotides covalently linked to acridine and quindoline derivatives through a threoninol linker. Bioorg. Med. Chem. 2010, 18, 7348-7356. [CrossRef] [PubMed]

7. Bouquin, N.; Malinovskii, V.L.; Guégano, X.; Liu, S.X.; Decurtins, S.; Häner, R. TTF-modified DNA. Chem. Eur. J. 2008, 14, 5732-5736. [CrossRef] [PubMed]

8. Schnippering, M.; Zahn, A.; Liu, S.X.; Leumann, C.; Decurtins, S. Synthesis and electrochemical properties of TTF modified oligodeoxynucleotides. Chem. Commun. 2009, 45, 5552-5554. [CrossRef] [PubMed]

9. Pérez-Rentero, S.; Gállego, I.; Somoza, A.; Ferreira, R.; Janoušek, J.; Bělohradský, M.; Stará, I.; Starý, I.; Eritja, R. Interstrand interactions on DNA duplexes modified by TTF units at the $3^{\prime}$ or $5^{\prime}$-ends. RSC Adv. 2012, 2, 4069-4071. [CrossRef]

10. Pérez-Rentero, S.; Somoza, A.; Grijalvo, S.; Janoušek, J.; Bělohradský, M.; Stará, I.; Starý, I.; Eritja, R. Biophysical and RNA interference inhibitory properties of oligonucleotides carrying tetrathiafulvalene groups at terminal positions. J. Chem. 2013, 2013, 650610. [CrossRef]

11. Yamada, J.; Akutsu, H. New trends in the synthesis of $\pi$-electron donors for molecular conductors and superconductors. Chem. Rev. 2004, 104, 5057-5083. [CrossRef] [PubMed]

12. Fourmigué, M.; Batail, P. Activation of hydrogen- and halogen-bonding interactions in tetrathiafulvalene-based crystalline molecular conductors. Chem. Rev. 2004, 104, 5379-5418. [CrossRef] [PubMed]

13. Jeppesen, J.O.; Nielsen, M.B.; Becher, J. Tetrathialfulvalene cyclophanes and cage molecules. Chem. Rev. 2004, 104, 5115-5131. [CrossRef] [PubMed]

14. Moonen, N.N.P.; Flood, A.H.; Fernández, J.M.; Stoddart, J.F. Towards a racional design of molecular switches and sensors from their basic building blocks. Top. Curr. Chem. 2005, 262, 99-132.

15. Kay, E.R.; Leigh, D.A.; Zerbetto, F. Synthetic molecular motors and mechanical machines. Angew. Chem. Int. Ed. 2007, 46, 72-191. [CrossRef] [PubMed]

16. Balzani, V.; Credi, A.; Venturi, M. Light powered molecular machines. Chem. Soc. Rev. 2009, 38, $1542-1550$. [CrossRef] [PubMed]

17. Fang, L.; Olson, M.A.; Benítez, D.; Tkatchouk, E.; Goddard, W.A., III; Stoddart, J.F. Mechanically bonded macromolecules. Chem. Soc. Rev. 2010, 39, 17-29. [CrossRef] [PubMed]

18. Rovira, C. Bis(ethylenethio)tetrathiafulvalene (BET-TTF) and related dissymmetrical electron donors: From the molecule to functional molecular materials and devices (OFETs). Chem. Rev. 2004, 104, 5289-5317. [CrossRef] [PubMed] 
19. Hasegawa, M.; Iyoda, M. Conducting supramolecular nanofibers and nanorods. Chem. Soc. Rev. 2010, 39, 2420-2531. [CrossRef] [PubMed]

20. Iyoda, M.; Hasegawa, M. Star-shaped tetrathiafulvalene oligomers towards the construction of conducting supramolecular assembly. Beilstein J. Org. Chem. 2015, 11, 1596-1613. [CrossRef] [PubMed]

21. Uji, H.; Kim, H.; Imai, T.; Mitani, S.; Sugiyama, J.; Kimura, S. Electronic properties of tetrathiafulvalene-modified cyclic- $\beta$-peptide nanotube. Biopolymers 2016, 106, 275-282. [CrossRef] [PubMed]

22. Pérez-Rentero, S.; Grijalvo, S.; Peñuelas, G.; Fàbrega, C.; Eritja, R. Thioctic acid derivatives as building blocks to incorporate DNA oligonucleotides onto gold nanoparticles. Molecules 2014, 19, 10495-10523. [CrossRef] [PubMed]

23. Estroff, L.A.; Hamilton, A.D. Water gelation by small organic molecules. Chem. Rev. 2004, 104, $1201-1218$. [CrossRef] [PubMed]

24. Liu, X.Y. Gelation with small molecules: From formation mechanism to nanostructure architecture. Top. Curr. Chem. 2005, 256, 1-37. [PubMed]

25. George, M.; Weiss, R.G. Molecular organogels. Soft matter comprised of low-molecular-mass organic gelators and organic liquids. Acc. Chem. Res. 2006, 39, 489-497. [CrossRef] [PubMed]

26. Weiss, R.G.; Terech, P. Molecular Gels: Materials with Self-Assembled Fibrillar Networks; Weiss, R.G., Terech, P., Eds.; Springer: Dordrecht, Netherlands, 2006.

27. Smith, D.K. Dendritic supermolecules-Towards controllable nanomaterials. Chem. Commun. 2006, 34-44. [CrossRef] [PubMed]

28. Zaccarelli, E. Colloidal gels: Equilibrium and non-equilibrium routes. J. Phys. Condens. Matter 2007, 19, 323101. [CrossRef]

29. Ajayaghosh, A.; Praveen, V.K.; Vijayakumar, C. Organogels as scaffolds for excitation energy transfer and light harvesting. Chem. Soc. Rev. 2008, 37, 109-122. [CrossRef] [PubMed]

30. Banerjee, S.; Das, R.K.; Maitra, U. Supramolecular gels 'in action'. J. Mater. Chem. 2009, 19, 6649-6687. [CrossRef]

31. Adams, D.J. Dipeptide and tripeptide conjugates as low-molecular-weight hydrogelators. Macromol. Biosci. 2011, 11, 160-173. [CrossRef] [PubMed]

32. Dawn, A.; Shiraki, T.; Haraguchi, S.; Tamaru, S.; Shinkai, S. What kind of "soft materials" can we design from molecular gels? Chem. Asian J. 2011, 6, 266-282. [CrossRef] [PubMed]

33. Yang, X.; Zhang, G.; Zhang, D. Stimuli responsive gels based on low molecular weight gelators. J. Mater. Chem. 2012, 22, 38-50. [CrossRef]

34. Draper, E.R.; Adams, D.J. Low-molecular-weight gels: The state of the art. Chem 2017, 3, 390-410. [CrossRef]

35. Sangeetha, N.M.; Maitra, U. Supramolecular gels: Functions and uses. Chem. Soc. Rev. 2005, 34, 821-836. [CrossRef] [PubMed]

36. Vintiloui, A.; Leroux, J.-C. Organogels and their use in drug delivery-A review. J. Control. Release 2008, 125, 179-192. [CrossRef] [PubMed]

37. Ulijn, R.V.; Smith, A.M. Designing peptide based nanomaterials. Chem. Soc. Rev. 2008, 37, 664-675. [CrossRef] [PubMed]

38. Piepenbrock, M.O.M.; Lloyd, G.O.; Clarke, N.; Steed, J.W. Metal- and anion-binding supramolecular gels. Chem. Rev. 2010, 110, 1960-2004. [CrossRef] [PubMed]

39. Du, X.; Zhou, J.; Shi, J.; Xu, B. Supramolecular hydrogelators and hydrogels: From soft matter to molecular biomaterials. Chem. Rev. 2015, 115, 13165-13307. [CrossRef] [PubMed]

40. Li, S.; John, V.T.; Irvin, G.C.; Bachakonda, S.H.; McPherson, G.L.; O'Connor, C.J. Synthesis and magnetic properties of a novel ferrite organogel. J. Appl. Phys. 1999, 85, 5965-5967. [CrossRef]

41. Kato, T. Self-assembly of phase-segregated liquid crystal structures. Science 2002, 295, 2414-2418. [CrossRef] [PubMed]

42. Kubo, W.; Kambe, S.; Nakade, S.; Kitamura, T.; Hanabusa, K.; Wada, Y.; Yanagida, S. Photocurrent-determining processes in quasi-solid-state dye-sensitized solar cells using ionic gel electrolytes. J. Phys. Chem. B 2003, 107, 4374-4381. [CrossRef]

43. Sanchez, C.; Llusar, M. Inorganic and hybrid nanofibrous materials templated with organogelators. Chem. Mater. 2008, 20, 782-820.

44. Díaz, D.D.; Kühbeck, D.; Koopmans, R.J. Stimuli-responsive nanostructured gels as reaction vessels and reusable catalysts. Chem. Soc. Rev. 2011, 40, 427-448. [CrossRef] [PubMed] 
45. Abdallah, D.J.; Weiss, R.G. Organogels and low molecular mass organic gelators. Adv. Mater. 2000, 12, 1237-1247. [CrossRef]

46. Tanaka, T. Gels. Sci. Am. 1981, 244, 110-123. [CrossRef]

47. DeRossi, D.; Kajiwara, Y.; Osada, Y.; Yamauchi, A. Polymer Gels: Fundamentals and Biomedical Applications; Plenum Press: New York, NY, USA, 1991.

48. Ahn, S.-K.; Kasi, R.M.; Kim, S.-C.; Sharma, N.; Zhou, Y. Stimuli-responsive polymer gels. Soft Matter 2008, 4 , 1151-1157. [CrossRef]

49. Zubarev, E.R.; Pralle, M.U.; Sone, E.D.; Stupp, S.I. Scaffolding of polymers by supramolecular nanoribbons. Adv. Mater. 2002, 14, 198-203. [CrossRef]

50. Huang, X.; Terech, P.; Raghavan, S.R.; Weiss, R.G. Kinetics of $5 \alpha$-cholestan-3 $\beta$-yl N-(2-naphthyl)carbamate/ $n$-alkane organogel formation and its influence on the fibrillar networks. J. Am. Chem. Soc. 2005, 127, 4336-4344. [CrossRef] [PubMed]

51. Ihara, H.; Takafuji, M.; Sakurai, T. Encyclopedia of Nanoscience and Nanotechnology; Nalwa, H.S., Ed.; American Scientific: California, CA, USA, 2004; Volume 9, pp. 473-495.

52. Shin, J.H.; Gardel, M.L.; Mahadeva, L.; Matsudaira, P.D.; Weitz, A. Relating microstructure to rheology of a bundled and cross-linked F-actin network in vitro. Proc. Natl. Acad. Sci. USA 2004, 101, 9636-9641. [CrossRef] [PubMed]

53. Fages, F. Low Molecular Mass Gelators. In Topics Current Chemistry; Fages, F., Ed.; Springer: Berlin/Heidelberg, Germany, 2005; Volume 256.

54. Jørgensen, M.; Bechgaard, K. Synthesis and structural characterization of a bis-arborol-tetrathiafulvalene gel: Toward a self-assembling "molecular" wire. J. Org. Chem. 1994, 59, 5877-5882. [CrossRef]

55. Le Gall, T.; Pearson, C.; Bryce, M.R.; Petty, M.C.; Dahlgaard, H.; Becher, J. Arborol-functionalised tetrathiafulvalene derivatives: Synthesis and thin-film formation. Eur. J. Org. Chem. 2003, 2003, 3562-3568. [CrossRef]

56. Yang, X.; Zhang, D.; Zhang, G.; Zhu, D. Tetrathiafulvalene (TTF)-based gelators: Stimuli responsive gels and conducting nanostructures. Sci. China Chem. 2011, 54, 596-602. [CrossRef]

57. Wang, C.; Zhang, D.; Zhu, D. A Low-molecular-mass gelator with an electroactive tetrathiafulvalene group: Tuning the gel formation by charge-transfer interaction and oxidation. J. Am. Chem. Soc. 2005, 127, 16372-16373. [CrossRef] [PubMed]

58. Kitamura, T.; Nakaso, S.; Mizoshita, N.; Tochigi, Y.; Shimomura, T.; Moriyama, M.; Ito, K.; Kato, T. Electroactive supramolecular self-assembled fibers comprised of doped tetrathiafulvalene-based gelators. J. Am. Chem. Soc. 2005, 127, 14769-14775. [CrossRef] [PubMed]

59. Puigmartí-Luis, J.; Laukhin, V.; del Pino, P.A.; Vidal-Gancedo, J.; Rovira, C.; Laukhina, E.; Amabilino, D.B. Supramolecular conducting nanowires from organogels. Angew. Chem. Int. Ed. 2007, 46, 238-241. [CrossRef] [PubMed]

60. Wang, X.-J.; Xing, L.-B.; Cao, W.-N.; Li, X.-B.; Chen, B.; Tung, C.-H.; Wu, L.-Z. Organogelators based on TTF supramolecular assemblies: Synthesis, characterization, and conductive property. Langmuir 2011, 27, 774-781. [CrossRef] [PubMed]

61. Wang, Y.; Liu, Y.; Jin, L.; Yin, B. T-shaped monopyridazinotetrathiafulvalene-amino acid diad based chiral organogels with aggregation-induced fluorescence emission. Soft Matter 2016, 12, 6373-6384. [CrossRef] [PubMed]

62. Liu, Y.; Dai, Y.; Yin, B. Gel properties of T-shaped tetrathiafulvalene-pyridazine conjugates and F4TCNQ-induced morphological transformation. New J. Chem. 2016, 40, 464-474. [CrossRef]

63. Kong, D.; Xia, Y.; Li, D.; Hou, R. Super organogelator based on tetrathiafulvalene with four amide derivatives and its F TCNQ chargetransfer complex. Supramol. Chem. 2017, 29, 102-110. [CrossRef]

64. Wang, C.; Chen, Q.; Sun, F.; Zhang, D.; Zhang, G.; Huang, Y.; Zhao, R.; Zhu, D. Multistimuli responsive organogels based on a new gelator featuring tetrathiafulvalene and azobenzene groups: Reversible tuning of the gel-sol transition by redox reactions and light irradiation. J. Am. Chem. Soc. 2010, 132, 3092-3096. [CrossRef] [PubMed]

65. Wang, C.; Sun, F.; Zhang, D.; Zhang, G.; Daoben, Z. Cholesterol-substituted tetrathiafulvalene (TTF) compound: Formation of organogel and supramolecular chirality. Chin. J. Chem. 2010, 28, 622-626. [CrossRef]

66. Canevet, D.; del Pino, A.P.; Amabilino, D.B.; Sallé, M. Varied nanostructures from a single multifunctional molecular material. J. Mater. Chem. 2011, 21, 1428-1437. [CrossRef] 
67. Liu, Y.; Yin, Z.; Jin, L.; Yin, B. Monopyrrolotetrathiafulvalene-based supramolecular organogels: Multi-stimuli responsiveness and formation of charge-transfer salt gels. Dyes Pigments 2017, 140, 500-511. [CrossRef]

68. Ahn, S.; Kim, Y.; Beak, S.; Ishimoto, S.; Enozawa, H.; Isomura, E.; Hasegawa, M.; Iyoda, M.; Park, Y. Synthesis and electrical conductivity of perchlorate-doped TTF-diamide nanofibers with double and triple helix structures. J. Mater. Chem. 2010, 20, 10817-10823. [CrossRef]

69. Ji, S.-F.; Sun, Y.-G.; Huo, P.; Shen, W.-C.; Huang, Y.-D.; Zhu, Q.-Y.; Dai, J. Effect of metal coordination on photocurrent response properties of a tetrathiafulvalene organogel film. Inorg. Chem. 2014, 53, 3611-3617. [CrossRef] [PubMed]

70. Amacher, A.M.; Puigmartí-Luis, J.; Geng, Y.; Lebedev, V.; Laukhin, V.; Krämer, K.; Hauser, J.; Amabilino, D.B.; Decurtins, S.; Liu, S.-X. Coordination-directed self-assembly of a simple benzothiadiazole-fused tetrathiafulvalene to low-bandgap metallogels. Chem. Commun. 2015, 51, 15063-15066. [CrossRef] [PubMed]

71. Sun, X.; Lai, G.; Li, Z.; Ma, Y.; Yuan, X.; Shen, Y.; Wang, C. Urethane tetrathiafulvalene derivatives: Synthesis, selfassembly and electrochemical properities. Beilstein J. Org. Chem. 2015, 11, 2343-2349. [CrossRef] [PubMed]

72. Mei, X.; Ouyang, J. Electronically and ionically conductive gels of ionic liquids and charge-transfer tetrathiafulvalene-tetracyanoquinodimethane. Langmuir 2011, 27, 10953-10961. [CrossRef] [PubMed]

73. Nalluri, S.K.M.; Shivarova, N.; Kanibolotsky, A.L.; Zelzer, M.; Gupta, S.; Frederix, P.W.J.M.; Skabara, P.J.; Gleskova, H.; Ulijn, R.V. Conducting nanofibers and organogels derived from the self-assembly of tetrathiafulvalene-appended dipeptides. Langmuir 2014, 30, 12429-12437. [CrossRef] [PubMed]

74. Liu, Y.; Wang, Y.; Jin, L.; Chen, T.; Yin, B. MPTTF-containing tripeptide-based organogels: Receptor for 2, 4, 6-trinitrophenol and multiple stimuli-responsive properties. Soft Matter 2016, 12, 934-945. [CrossRef] [PubMed]

75. Lu, L.; Cocker, T.M.; Bachman, R.E.; Weiss, R.G. Gelation of organic liquids by some $5 \alpha$-cholestan- $3 \beta-y 1$ $\mathrm{N}$-(2-aryl)carbamates and 3 $\beta$-cholesteryl 4-(2-anthrylamino)butanoates. How important are H-bonding interactions in the gel and neat assemblies of aza aromatic-linker-steroid gelators? Langmuir 2000, 16, $20-34$. [CrossRef]

76. Schiller, J.; Alegre-Requena, J.V.; Marqués-López, E.; Herrera, R.P.; Casanovas, J.; Alemán, C.; Díaz, D.D. Self-assembled fibrillar networks of a multifaceted chiral squaramide: Supramolecular multistimuli-responsive alcogels. Soft Matter 2016, 12, 4361-4374. [CrossRef] [PubMed]

77. Simonsen, K.B.; Svenstrup, N.; Lau, J.; Simonsen, O.; Mork, P.; Kristensen, G.J.; Becher, J. Sequential functionalization of bis-protected tetrathiafulvalene-dithiolates. Synthesis 1996, 1996, 407-418. [CrossRef]

78. Zhao, B.T.; Blesa, M.J.; Le Derf, F.; Canevet, D.; Benhaoua, C.; Mazari, M.; Allain, M.; Sallé, M. Carboxylic acid derivatives of tetrathiafulvalene: Key intermediates for the synthesis of redox-active calixarene-based anion receptors. Tetrahedron 2007, 63, 10768-10777. [CrossRef]

79. Toniolo, C.; Palumbo, M. Solid-state infrared absorption spectra and chain arrangement in some synthetic homooligopeptides in the intermolecularly hydrogen-bonded pleated-sheet $\beta$-conformation. Biopolymers 1977, 16, 219-224. [CrossRef] [PubMed]

80. Fischer, R.E.; Tadic-Galeb, B.; Yoder, P.R. Optical System Design, 2nd ed.; McGraw Hill: New York, NY, USA, 2008.

(C) 2018 by the authors. Licensee MDPI, Basel, Switzerland. This article is an open access article distributed under the terms and conditions of the Creative Commons Attribution (CC BY) license (http:// creativecommons.org/licenses/by/4.0/). 